\title{
Projection of Future Precipitation and Temperature Change over the Transboundary Koshi River Basin Using Regional Climate Model PRECIS
}

\author{
Rupak Rajbhandari ${ }^{*}$, Arun Bhakta Shrestha ${ }^{2}$, Santosh Nepal ${ }^{2}$, Shahriar Wahid ${ }^{2}$ \\ ${ }^{1}$ Department of Meteorology, Tri-Chandra Campus, Tribhuvan University, Kathmandu, Nepal \\ ${ }^{2}$ International Centre for Integrated Mountain Development, Kathmandu, Nepal \\ Email: *rupak.rajbhandari@gmail.com
}

How to cite this paper: Rajbhandari, R., Shrestha, A.B., Nepal, S. and Wahid, S. (2018) Projection of Future Precipitation and Temperature Change over the Transboundary Koshi River Basin Using Regional Climate Model PRECIS. Atmospheric and Climate Sciences, 8, 163-191. https://doi.org/10.4236/acs.2018.82012

Received: January 29, 2018

Accepted: April 10, 2018

Published: April 16, 2018

Copyright $\odot 2018$ by authors and Scientific Research Publishing Inc. This work is licensed under the Creative Commons Attribution International License (CC BY 4.0).

http://creativecommons.org/licenses/by/4.0/

(c) (i) Open Access

\begin{abstract}
The Koshi river basin sustains the livelihoods of millions of people in the upstream and downstream areas of the basin. People rely on monsoon rainfall for agricultural production, hydropower generation and other livelihood activities. Climate change is expected to have serious implication on its environment. To reduce the adverse impacts of disasters and to better understand the implication of climate change for the sustainable development, initiative in this regard is necessary. Analysis of past meteorological trends and future climate projections can give us a sense of what to expect and how to prepare ourselves and manage available resources. In this paper, we have used a high-resolution climate model, viz., Providing REgional Climates for Impacts Studies (PRECIS), to project future climate scenario over the Koshi river basin for impact assessment. Three outputs of the Quantifying Uncertainties in Model Prediction (QUMP) simulations have been used to project the future climate. These simulations were selected from the 17-member Perturbed Physics Ensemble (PPE) using Hadley Centre Couple Model (HadCM3) based on the IPCC SRES A1B emission scenario. The future projections are analysed for three time slices 2011-2040 (near future), 2041-2070 (middle of the century) and 2071-2098 (distant future). Despite quantitative wet and cold bias, the model was able to resolve the seasonal pattern reasonably well. The model projects a decrease in rainfall in the near future and a progressive increase towards the end of the century. The projected change in rainfall is non-uniform, with increase over the southern plains and the middle mountains and decrease over the trans-Himalayan region. Simulation suggests that rainy days will be less frequent but more intense over the southern plains towards the
\end{abstract}


end of the century. Further, the model projections indicate significant warming towards the end of the century. The rate of warming is slightly higher over the trans-Himalayan region during summer and over the southern plains during winter.

\section{Keywords}

Future Climate, Climate Projection, PRECIS, Koshi, Himalaya

\section{Introduction}

The Himalayan region is highly influenced by monsoon rainfall. About $80 \%$ of the annual total rainfall occurs during the monsoon season (June-September) in the eastern parts of the Himalayas [1], but the role of monsoon decreases as it proceeds west and the influence of westerly winter disturbances becomes more prominent. Over western Himalaya, the contribution of winter precipitation is as much as $50 \%$ of the total [2]. Large populations across this region rely heavily on monsoon rainfall for their agricultural production, hydro-electricity generation and other livelihood activities [3]. In the global level, the increased emissions of greenhouse gases and short-lived climate pollutants (SLCP) are modifying short-term and seasonal climate variability [4]. Such changes can have profound impact on sectors like agriculture, water resources and human health in the Himalayan region [5] [6]. Variability of future climate is a matter of great concern for resources management and planning [7] [3]. Understanding the nature of climate change has thus become essential. Many climate modelling groups have performed future climate simulations under IPCC's different emission scenarios [8]. The major sources of water in the Hindu Kush Himalaya (HKH) - snow and ice reserves are considered vulnerable to climate change [9] [10]. These models indicate that future rainfall and temperature is likely to change but the magnitude of these changes will be different in various ecological regimes. In the case of the Himalayas, too, the impact is likely to be different across the region given the sharp altitudinal difference across the mountains extending from east to west. As a result of the differences in precipitation climatology, the hydrological regime of the region is also quite different from east to west. Eastern Himalaya has significantly longer snow melt period compared to western Himalaya and global warming may increase already observed glacier retreat [11]. Eastern river basin-Brahmaputra-is heavily influenced by the summer monsoon whereas western river basin-Indus-relies on melting of snow and glaciers [12] [5].

There is scant available literature on the Himalayan region that uses climate change scenarios based on high-resolution climate models [13] some previous studies on climate change scenarios include [14] [15] [16] [17] were developed over the sub-continental domain. For impact assessment, particularly in the water sector, scenarios developed over river basins have been found to be useful 
[18]. This study attempts to examine future changes in climate over the Koshi river basin using three simulation outputs from the regional climate model PRECIS based on the SRES A1B scenario [19].

The Koshi River is the largest tributary of the Ganges and is one of the key transboundary river basins in the Hindu Kush Himalayan (HKH) region. Tributaries of Koshi river originates from the high-altitude Himalayas including trans-Himalaya (Tibetan plateau) and flow through Nepal's mid-mountains, hills and plains (lowland region of Nepal and India). Koshi basin covers approximately 87,970 square kilometres; $32 \%$ of this area lies in China, $45 \%$ in Nepal and 22\% in India [20]. Physiographic distribution based on altitude and major river system is shown in Figure 1. The basin is particularly prone to natural hazards such as glacial lake outburst floods (GLOF), landslide and debris flow, droughts and floods [21]. Neupane et al. [22] have suggested that climate change is likely to lead to an increase in water scarcity in the basin, which will ultimately influence the agro-based livelihoods of the basin. The temperature analysis by Agarwal et al. [23] suggested that seasonal as well as mean annual minimum and maximum temperature will increase in the future. The maximum temperature was reported to be increasing at the rate of $0.058^{\circ} \mathrm{C} /$ year in the Nepal part of the Koshi basin [23]. The precipitation trend is spatially less homogenous compared to temperature [24]. To better understand the future

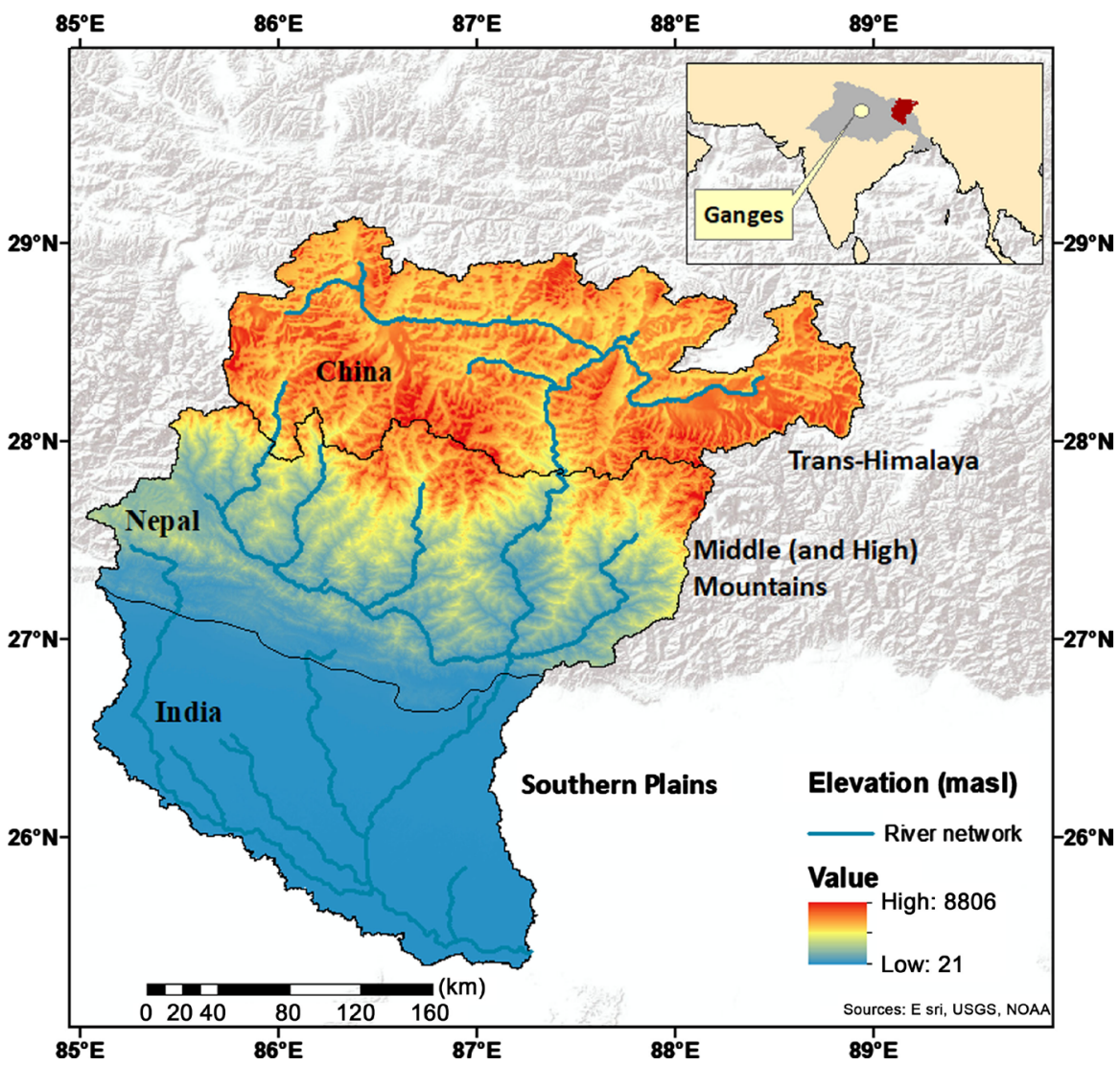

Figure 1. Koshi basin location map with three physiographic zones (trans-Himalaya, middle mountains and southern plain) and major river system. 
precipitation and temperature patterns, this study attempts to examine future climate change scenarios in the basin using PRECIS outputs.

In the context of climate change, the hazards may increase in magnitude and frequency [25] [3]. Additionally, the changes in physical processes and management practices in upstream areas might affect water availability in downstream areas [26].

Due to the complex topography of the Himalaya, rainfall distribution over the region is highly heterogeneous [27] [28] [29] [30]. The sudden rise of the Himalayas from the Terai plains within a span of a few kilometres results in various types of climate [31] [32] [33], and can influence the atmospheric flow pattern through orographic effects. Understanding spatial and temporal distribution of climate variables for the present and future is essential for understanding future impacts on different sectors, including water resources, agriculture and other sectors. The Koshi basin covers three different physiographic zones: trans-Himalaya in the northern Tibetan part of China; middle mountains and high Himalayas (hereafter referred to as middle mountains) in the centre (Nepal); and the southern plains of Nepal and India, as shown in Figure 1.

\section{Data}

Complex climate regimes and geographical features in the region poses a considerable difficulty in simulating observed climate scenarios. Panday et al [13] suggests that high resolution dynamical downscaling requires techniques that improves better representation of topography to simulate monsoon and other hydrological process in the region.

As Kripalani et al. [34] have noted, only a few GCMs (out of 22) effectively captured the spatial variability of the Indian summer monsoon. Among these models, HadCM3 (along with six other models) has simulated the inter-annual summer monsoon mean and variability well. The three QUMP simulations namely, Q0, Q1 and Q14 were able to simulate gross features of the Indian summer monsoon. These three output have been validated for their skill in simulating the present climate over India [35]. Further, outputs have been used to project the future climate over India [15], Himalayan region [17] and Indus basin [18]. In this paper, the outputs of these three simulations were used to project the changes in future climate from the base period 1961-1990 over the Koshi basin. These simulations, run at IITM (Q0, Q1 and Q14), have been configured to $1.5^{\circ} \mathrm{N}$ to $38^{\circ} \mathrm{N}$ and $56^{\circ} \mathrm{E}$ to $103^{\circ} \mathrm{E}$ of whose output were provided to International Centre for Integrated Mountain Development (ICIMOD).

For the current study, APHRODITE's (Asian Precipitation - Highly - Resolved Observational Daily Integration Towards Evaluation

http://www.chikyu.ac.jp/precip/) gridded data has been taken as the base data for evaluation of the seasonal rainfall simulation. These gridded datasets are publicly available at a resolution of $0.25^{\circ}$ for the monsoon Asian domain $\left(60^{\circ} \mathrm{E}\right.$ $150^{\circ} \mathrm{E}$ and $15^{\circ} \mathrm{N}-55^{\circ} \mathrm{N}$ ). APHRODITE's rainfall data is based on rain-gauge 
observations and depict the areal distribution and variability of the rainfall over the Himalayas [36]. APHRODITE rainfall product has been widely used for scientific assessment in the Himalayan region [37]. It is found to be better than other gridded products such as TRMM and gives better precipitation estimates [38] [39]. For quantitative and qualitative comparison, we have used version APHRO_V1101, which includes more rain-gauge data than the previous version [40].

To evaluate the temperature outputs of the PRECIS model, we have taken APHRODITE's mean temperature publicly available for monsoon Asia domain from 1961-2007 [41] and maximum and minimum temperature from Princeton University Hydroclimatology Group Bias Corrected Meteorological Forcing Datasets [42] available globally from $1947-2007$ at $1.0^{\circ} \times 1.0^{\circ}$ resolution. Further, the Princeton data is of coarse resolution so for the present study, we have used daily temperature range from this dataset and applied it to APHRODITE's mean daily temperature to build maximum and minimum temperatures of $0.25^{\circ}$ resolution.

\section{Results and Discussion}

\subsection{Precipitation}

To evaluate the model in representing the regional climatological features, summer monsoon (June-September) rainfall characteristics have been studied. Table 1 provides seasonal rainfall statistics for the three simulations for the baseline period (1961-1990) over the whole basin, the trans-Himalayan part, the middle mountain area and the southern plains. The rainfall statistics are computed from area averaged daily rainfall and temperature over transboundary Koshi basin and its three sub-divisions. Rainfall simulations for the whole basin compared with observed (APHRODITE) resulted in a substantial wet bias over

Table 1. Baseline (1961-1990) seasonal and annual mean rainfall (mm) and standard deviation ( $\mathrm{mm}$ ) with annual rainy days (a) whole Koshi basin (b) plains Koshi (c) middle mountains Koshi and (d) trans-Himalayan Koshi.

(a)

\begin{tabular}{|c|c|c|c|c|c|c|}
\hline & DJF & MAM & JJAS & $\mathrm{ON}$ & Annual & Rainy days \\
\hline \multicolumn{7}{|c|}{ Mean } \\
\hline Observed & 26 & 123 & 818 & 57 & 1024 & 169 \\
\hline Q0 & 87 & 349 & 1030 & 197 & 1663 & 200 \\
\hline Q1 & 91 & 298 & 1089 & 154 & 1632 & 189 \\
\hline Q14 & 130 & 298 & 1086 & 162 & 1676 & 203 \\
\hline \multicolumn{7}{|c|}{ Standard Deviation } \\
\hline Observed & 14.1 & 35.4 & 93.0 & 36.4 & 115.0 & 13 \\
\hline Q0 & 51.1 & 106.1 & 119.1 & 104.9 & 186.2 & 13 \\
\hline Q1 & 49.5 & 88.0 & 155.1 & 70.6 & 201.4 & 11 \\
\hline Q14 & 57.9 & 87.5 & 137.1 & 77.4 & 162.0 & 12 \\
\hline
\end{tabular}


(b)

\begin{tabular}{ccccccc}
\hline & DJF & MAM & JJAS & ON & Annual & Rainy days \\
\hline Observed & 22 & 101 & 890 & 72 & 1085 & 130 \\
Q0 & 42 & 249 & 795 & 124 & 1210 & 159 \\
Q1 & 39 & 169 & 835 & 108 & 1151 & 141 \\
Q14 & 65 & 200 & 885 & 122 & 1272 & 155 \\
\hline Observed & 13.0 & 46.8 & 192.3 & 59.1 & 210.0 & 14 \\
Q0 & 23.7 & 130.0 & 137.2 & 66.6 & 205.5 & 14 \\
Q1 & 29.5 & 73.3 & 113.4 & 67.0 & 173.8 & 15 \\
Q14 & 30.0 & 100.6 & 106.8 & 68.5 & 174.3 & 12 \\
\hline
\end{tabular}

(c)

\begin{tabular}{ccccccc}
\hline & DJF & MAM & JJAS & ON & Annual & Rainy days \\
\hline Observed & 34 & 205 & 1210 & 79 & 1528 & 188 \\
Q0 & 134 & 508 & 1318 & 304 & 2264 & 211 \\
Q1 & 143 & 447 & 1468 & 230 & 2288 & 204 \\
Q14 & 195 & 438 & 1404 & 234 & 2271 & 218 \\
\hline Observed & 21.2 & 51.9 & 112.9 & 46.1 & 144.0 & 14 \\
Q0 & 84.0 & 154.5 & 198.1 & 179.6 & 291.8 & 14 \\
Q1 & 78.8 & 143.1 & 286.4 & 112.4 & 356.2 & 11 \\
Q14 & 91.4 & 120.7 & 255.5 & 120.3 & 276.1 & 14 \\
\hline
\end{tabular}

(d)

\begin{tabular}{ccccccc}
\hline & DJF & MAM & JJAS & ON & Annual & Rainy days \\
\hline \multicolumn{7}{c}{ Mean } \\
\hline Observed & 20 & 50 & 327 & 24 & 421 & 112 \\
Q0 & 69 & 298 & 1086 & 162 & 1615 & 177 \\
Q1 & 71 & 231 & 866 & 104 & 1272 & 191 \\
Q14 & 101 & 217 & 890 & 113 & 1321 & 8 \\
\hline Qbserved & 14.8 & 0.0 & 0.0 & 0.0 & 0.0 & 11 \\
Q1 & 39.7 & 87.5 & 137.1 & 77.4 & 162.0 & 11 \\
\hline
\end{tabular}


the basin. Of the three simulations, annual total for Q1 simulation was found to be $1632 \mathrm{~mm}$ with $201 \mathrm{~mm}$ standard deviation closest to the observed value of $1024 \mathrm{~mm}$. Q0 and Q14 simulations estimated annual total of $1663 \mathrm{~mm}$ and 1676 $\mathrm{mm}$ with standard deviations of $186 \mathrm{~mm}$ and $162 \mathrm{~mm}$, respectively. Breaking down the basin into three zones shows that Q1 simulation with $1151 \mathrm{~mm}$ is closest to the observed value $1085 \mathrm{~mm}$ over the southern plains. A substantial wet bias is simulated by PRECIS over the trans-Himalayan area (rain shadow area). The estimation here is as much as three times the observed (Table 1(d)) value.

Ensemble average of the three simulations shows an overestimation (bias) of $1.75 \mathrm{~mm}$ per day. Several previous studies have reported a wet bias over the South Asia domain [14] [16] [18]. A PRECIS simulation output study over India showed Q0 and Q14 simulations to have a wet bias and Q1 a dry bias [15], whereas other similar studies over India showed a wet bias [14].

Monthly precipitation distribution for the whole basin and its breakdown into the three physiographic zones is provided in Figure 2. The model captures the monthly accumulation pattern. For July and August, the model results and the observed data were quite close, but for the rest of year, the model overestimated the observed total. Over the middle mountains and the southern plains, the observed data exceeded the model total for July and August, and for the remaining months, the model totals were higher.

Rainfall distribution for the monsoon season (June-September) is provided in Figure 3. Central parts of the basin (middle mountains) where the rainfall maximum is observed and the north-south gradient is well captured by the
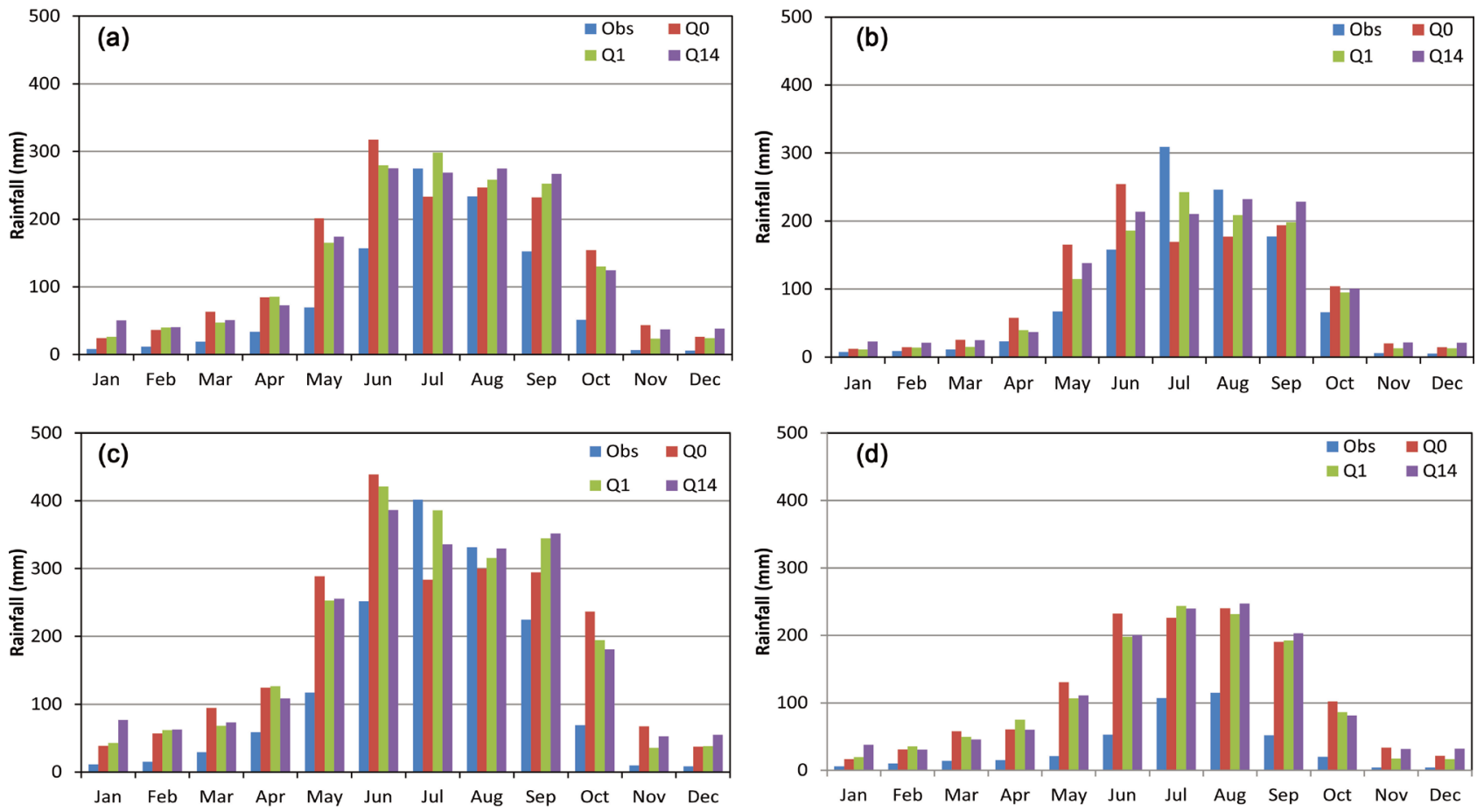

Figure 2. Annual cycle of mean rainfall. (a) Whole Koshi basin (b) southern plains (c) middle mountains (d) trans-Himalaya. 

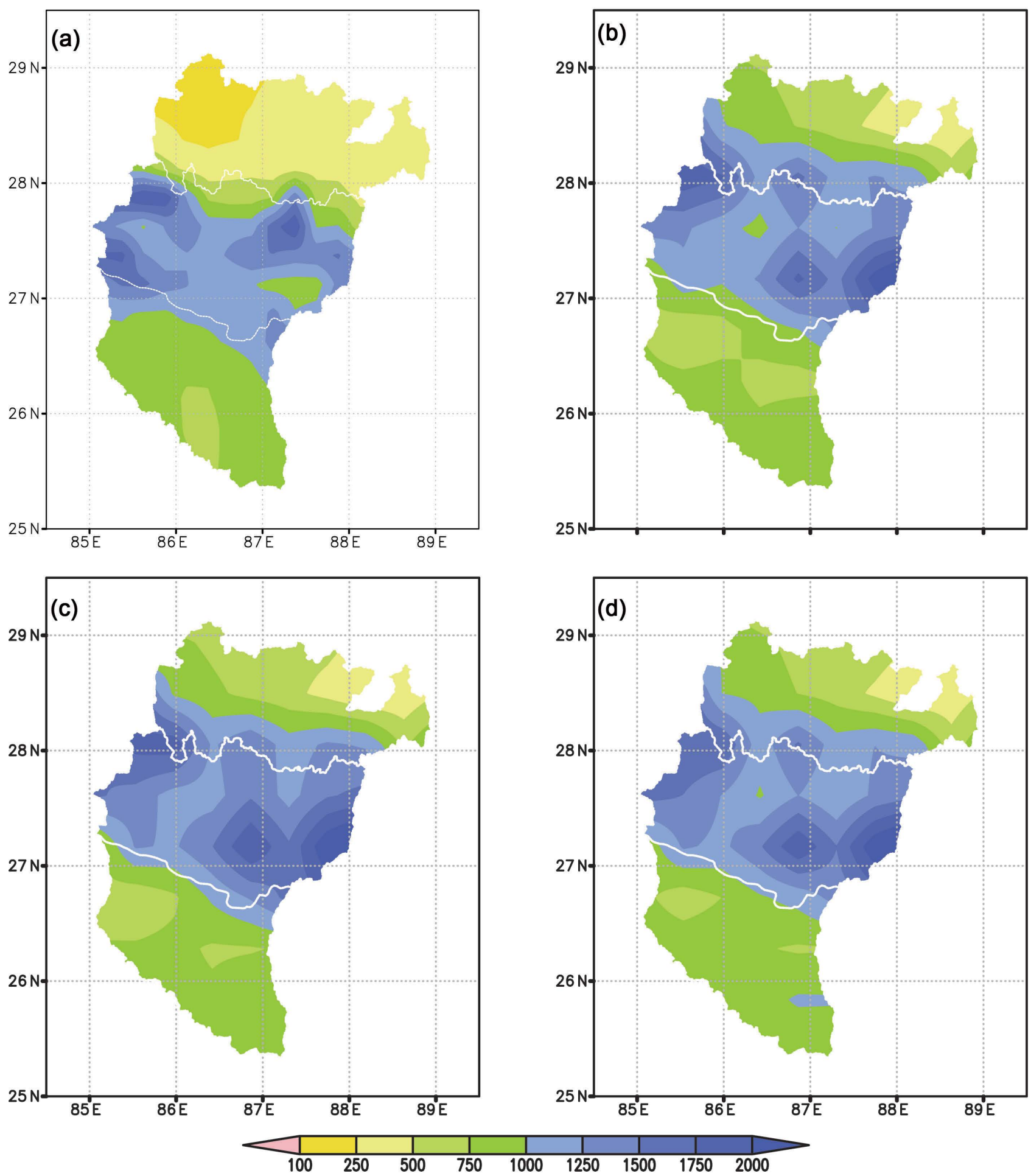

Figure 3. Seasonal distribution of rainfall (June-September) in mm. (a) APHRODITE (b) Q0 PRECIS simulation, (c) Q1 simulation (d) Q14 simulation.

PRECIS simulation. However there is a wet bias extending slightly to the north part of the basin. Winter season spatial rainfall distribution (figure not shown) also shows over estimation by the simulation while the north-south gradient in rainfall is captured. 


\subsection{Rainfall Frequency and Intensity}

A day with rainfall greater than or equal to $1.0 \mathrm{~mm}$ is considered a rainy day. Rainfall frequency is higher over the middle mountain areas and progressively decreases from north to south (Figure 4). The PRECIS simulations overestimated the number of rainy days but the distribution pattern is similar.
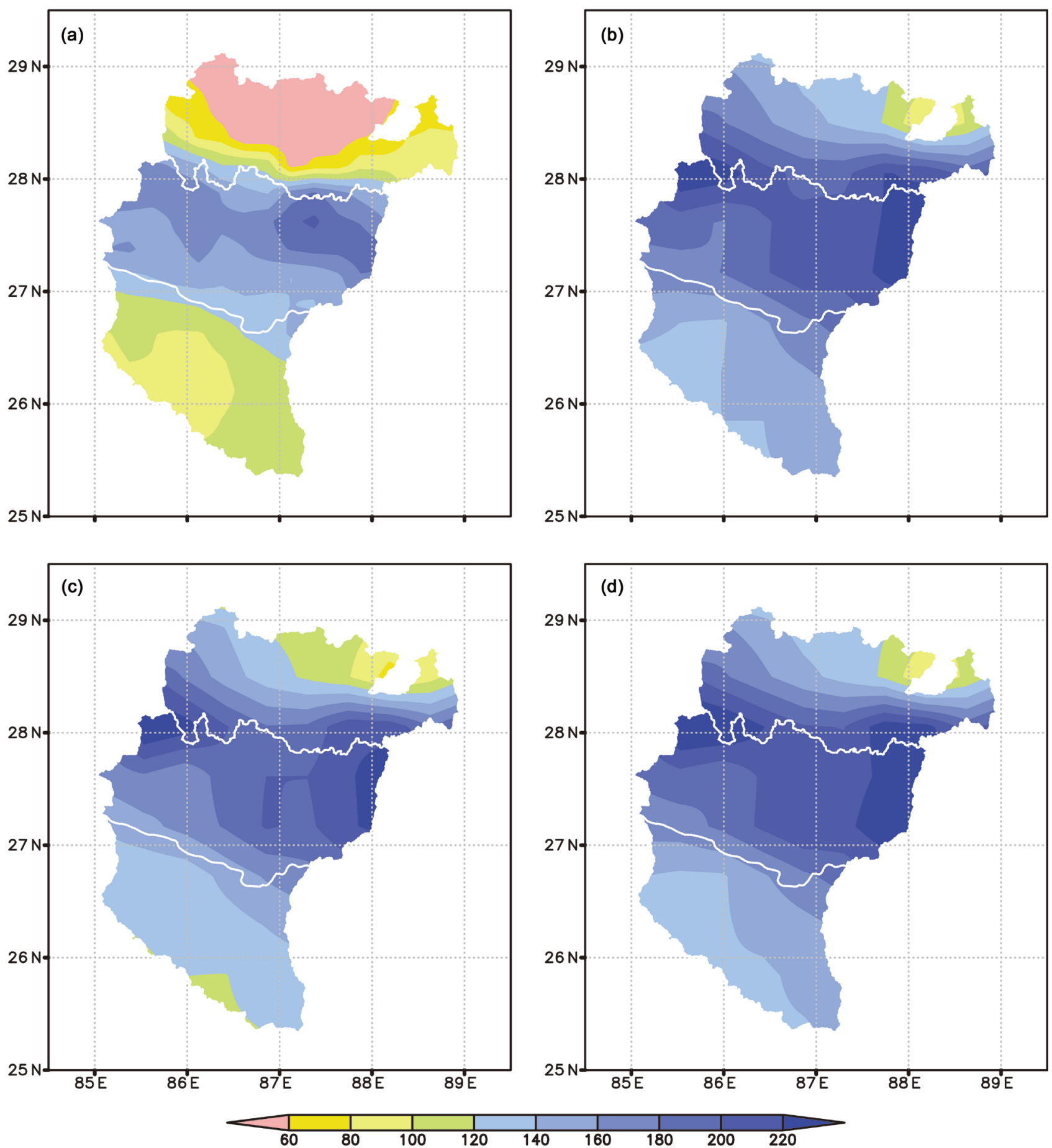

Figure 4. Number of rainy days as simulated by PRECIS compared with the observed. (a) APHRODITE (b) Q0 simulation (c) Q1 simulation (d) Q14 simulation. 
APHRODITE estimated 169 annual rainy days for the baseline period 19611990, whereas PRECIS estimated 200, 189, and 203 days for the Q0, Q1, and Q14 simulation respectively (Table $1(\mathrm{a})$ ). Rainfall intensity pattern on a rainy day (Figure 5) is higher over the central parts of the basin and lower in the northern parts. However, in the southern plains, rainfall intensity is between $6-10 \mathrm{~mm} /$ day in PRECIS simulations compared to the $8-12 \mathrm{~mm}$ /day for APHRODITE.
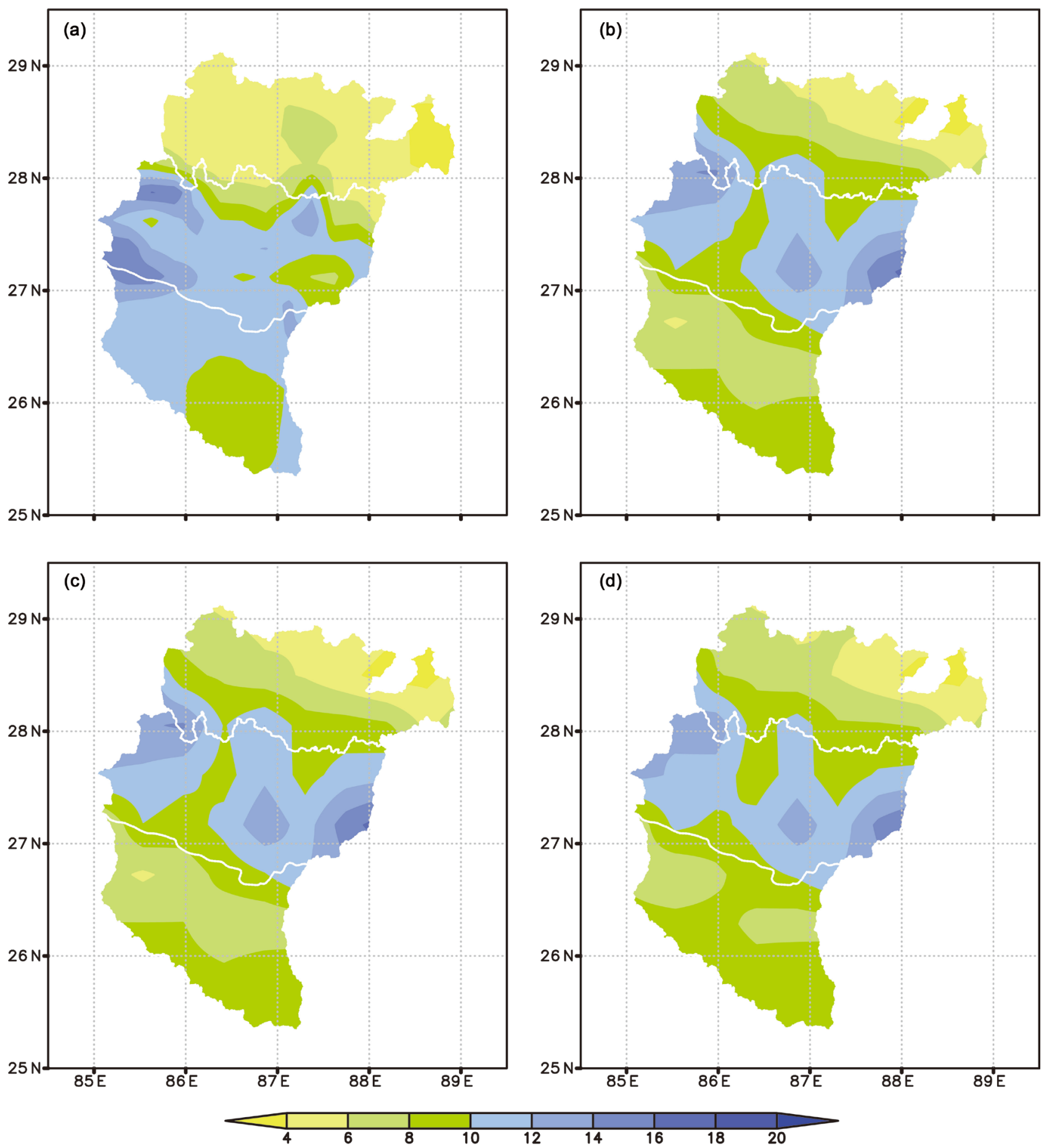

Figure 5. Simple daily rainfall intensity on a rainy day (mm/day). (a) APHRODITE (b) Q0 (c) Q1 (d) Q14 PRECIS simulation. 


\subsection{Temperature}

Seasonal and annual temperature $\left({ }^{\circ} \mathrm{C}\right)$ and its standard deviation is provided in Table 2 for the whole basin and the different physiographic zones viz., southern plains, middle mountains and trans-Himalaya. The annual cycle of mean monthly temperature is shown in Figure 6. The annual march of temperature is

Table 2. Seasonal and annual average temperature $\left({ }^{\circ} \mathrm{C}\right)$ and standard deviation for the whole basin (top left), southern plains (top right), middle mountains (bottom left) and trans-Himalayan area (bottom right).

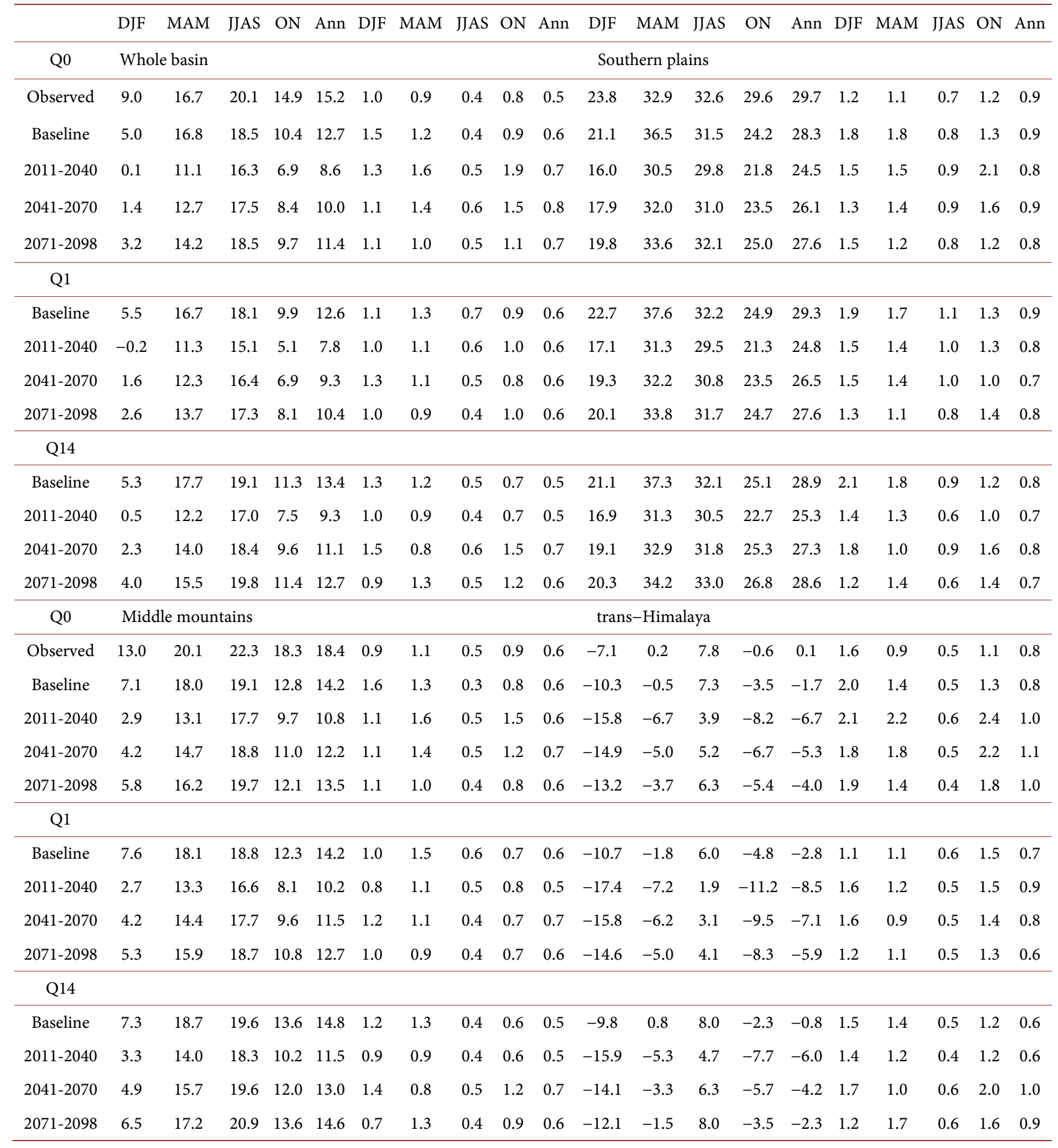



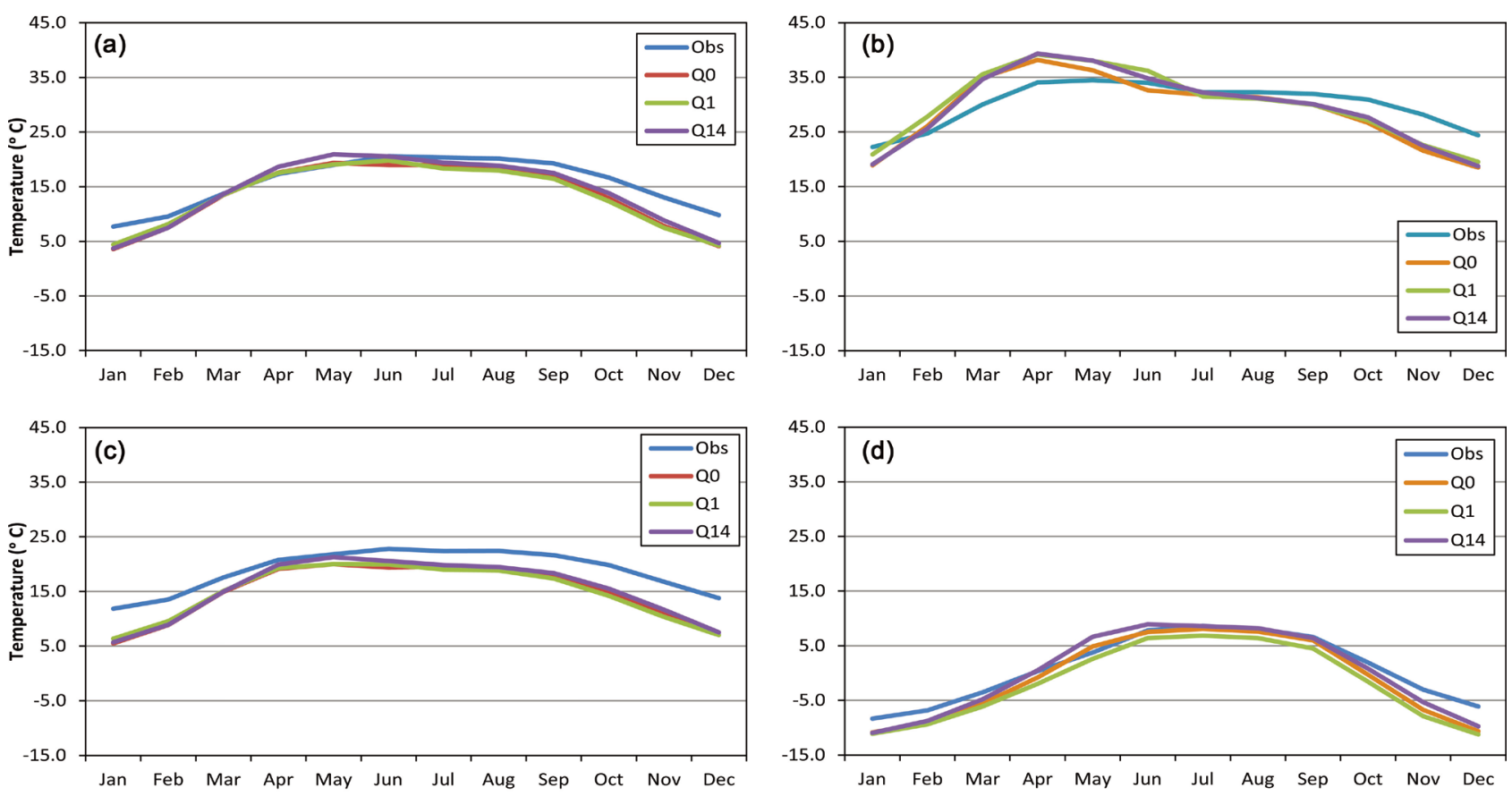

Figure 6. Annual cycle of mean monthly temperature (a) Koshi basin

(b) southern plains (c) middle mountains trans-Himalaya.

well captured by the model. The Q0 and Q1 simulation values were quite close to the observed, while the Q14 simulation shows a warm bias during April and May. In the middle mountain areas, the PRECIS underestimates the observed data throughout the year, although the gap is little for April and May. In the southern plains, PRECIS overestimates the pre-monsoon season, whereas the observed data overestimate the rest of the time period. In the trans-Himalayan zone, the simulated and observed data match well, although PRECIS slightly underestimates the observed data, except for the monsoon season. The temperature is underestimated from July for the three simulations. These biases may be due to a coarse network of monitoring stations over the high-altitude mountainous areas, as the stations are generally located in the valley bottoms.

Summer and winter distributions of air temperature as simulated by PRECIS are given in Figure 7 and Figure 8 respectively. Temperature distribution over the Koshi basin closely follows the topography and is in general agreement with the observed, but with a cold bias over the trans-Himalaya and a slight warm bias towards the southern plains.

\subsection{Highest Maximum and Lowest Minimum Temperatures}

Baseline simulations of the extreme maximum and minimum temperatures are shown in Figure 9 and Figure 10 respectively. They closely match the observed pattern. Both the highest maximum and lowest minimum show a warm bias over all parts of the basin. The model simulates the highest temperature exceeding $50^{\circ} \mathrm{C}$ over the southern plains (mostly over India) whereas in the observed, it is seen over the southernmost part only. 


\section{Projection of the Future Climate}

The continuous output from 1961 to 2098 from PRECIS based on IPCC SRES A1B scenario are divided into baseline period (1961-1990), and future projections from 2011 to 2098 are divided into three time slices 2011-2040 (near future), 2041-2070 (middle of the first century) and 2071-2098 (end of the century).
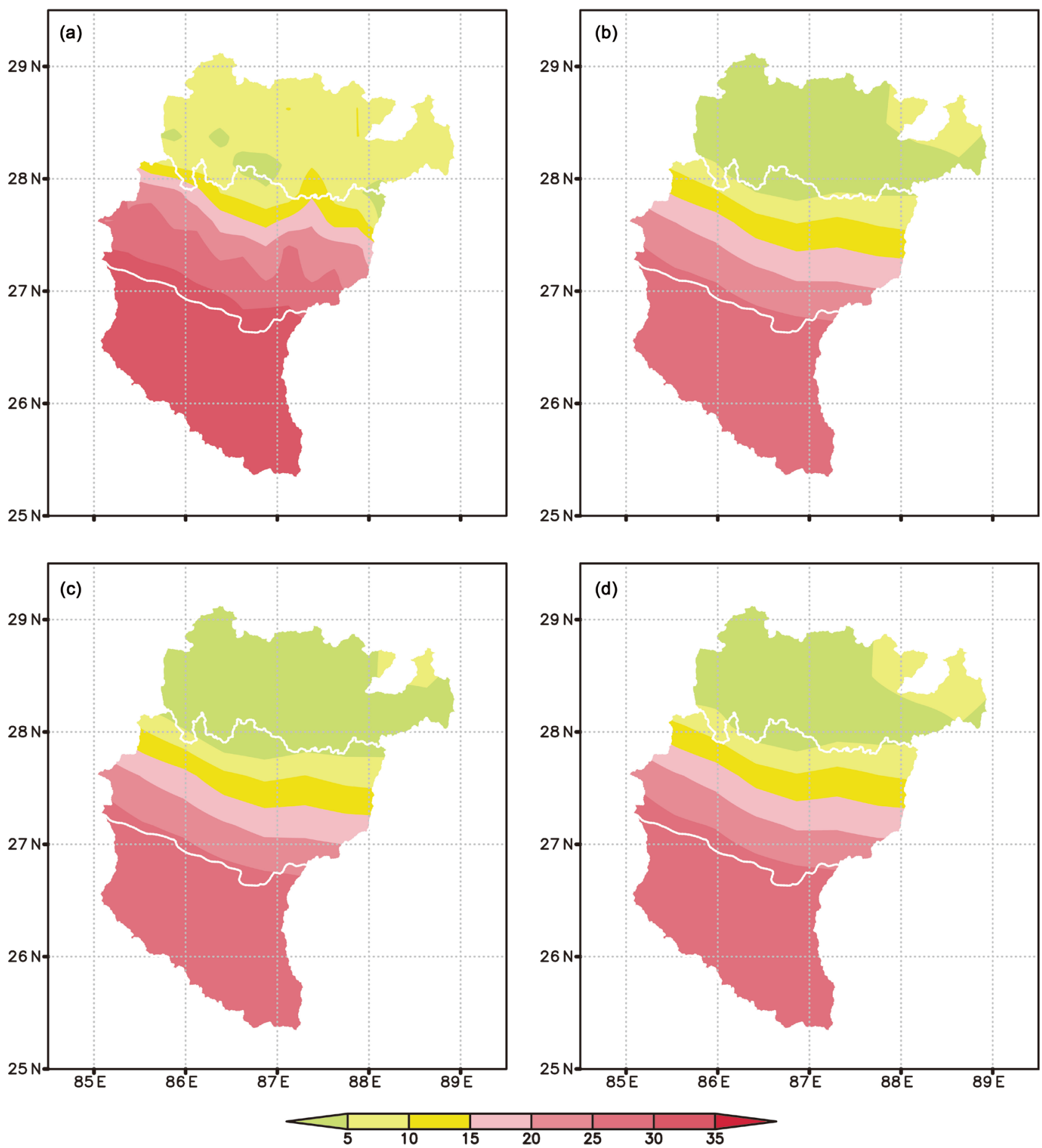

Figure 7. Spatial distribution of summer season mean temperature $\left({ }^{\circ} \mathrm{C}\right.$ ) (a) APHRODITE compared with three PRECIS simulations (b) Q0 (c) Q1 and (d) Q14. 

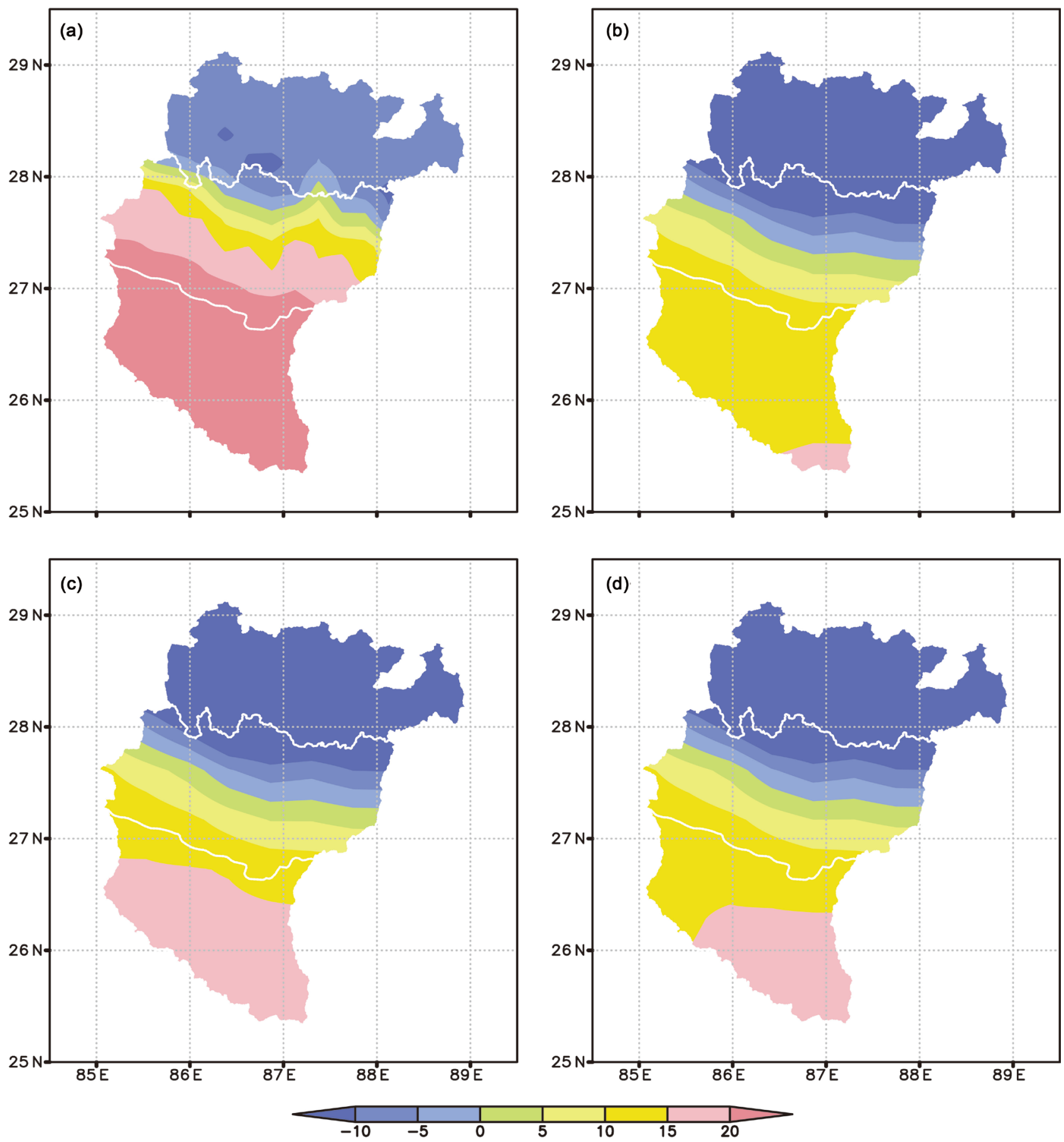

Figure 8. Winter season mean surface air temperature in ${ }^{\circ} \mathrm{C}$. (a) APHRODITE (b) PRECIS Q0 simulation (c) Q1 simulation (d) Q14 simulation.

Their results are discussed below.

\subsection{Projected Change in Normal Rainfall}

Projected changes in summer rainfall for the whole basin and the three physiographic zones for the three time slices in the future viz., 2011-2040, 2041-2070, and 2071-2098 are given in Figure 11. Over the whole Koshi basin, all three si- 
mulations show decrease in rainfall in the near future and then gradual increase till the end of the century. However over the southern plains, except for Q14 in the 20 's time slice, there is progressive increase in summer rainfall. Over the middle mountain zone, rainfall is projected to decrease in the near future and then progressively increase from the present baseline towards the end of the century. The rainfall is projected to decrease from the baseline period over the trans-Himalayan zone.
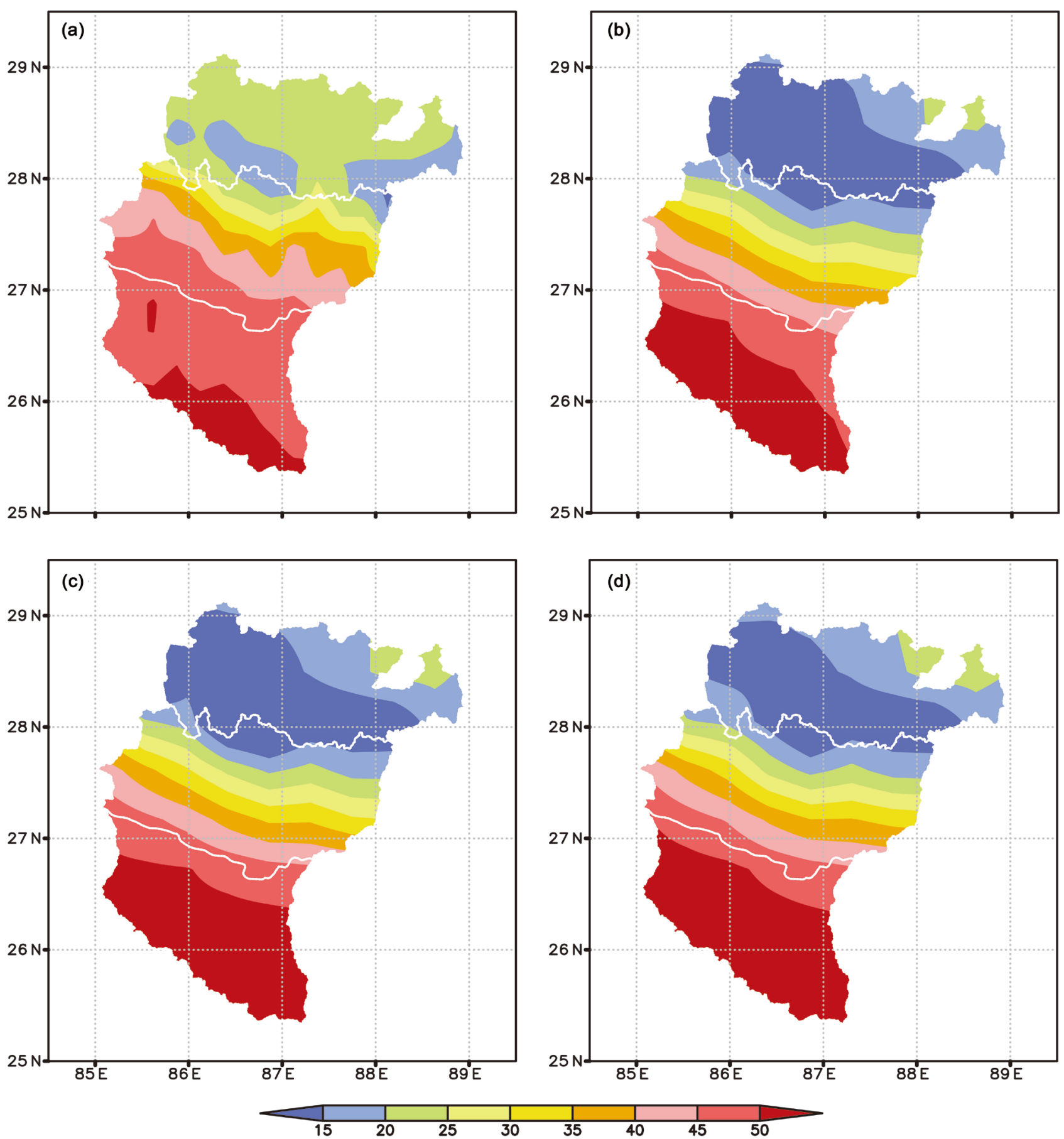

Figure 9. Highest maximum temperature ( $\left.{ }^{\circ} \mathrm{C}\right)$. (a) APHRODITE (b) Q0 simulation (c) Q1 simulation (d) Q14 simulation. 

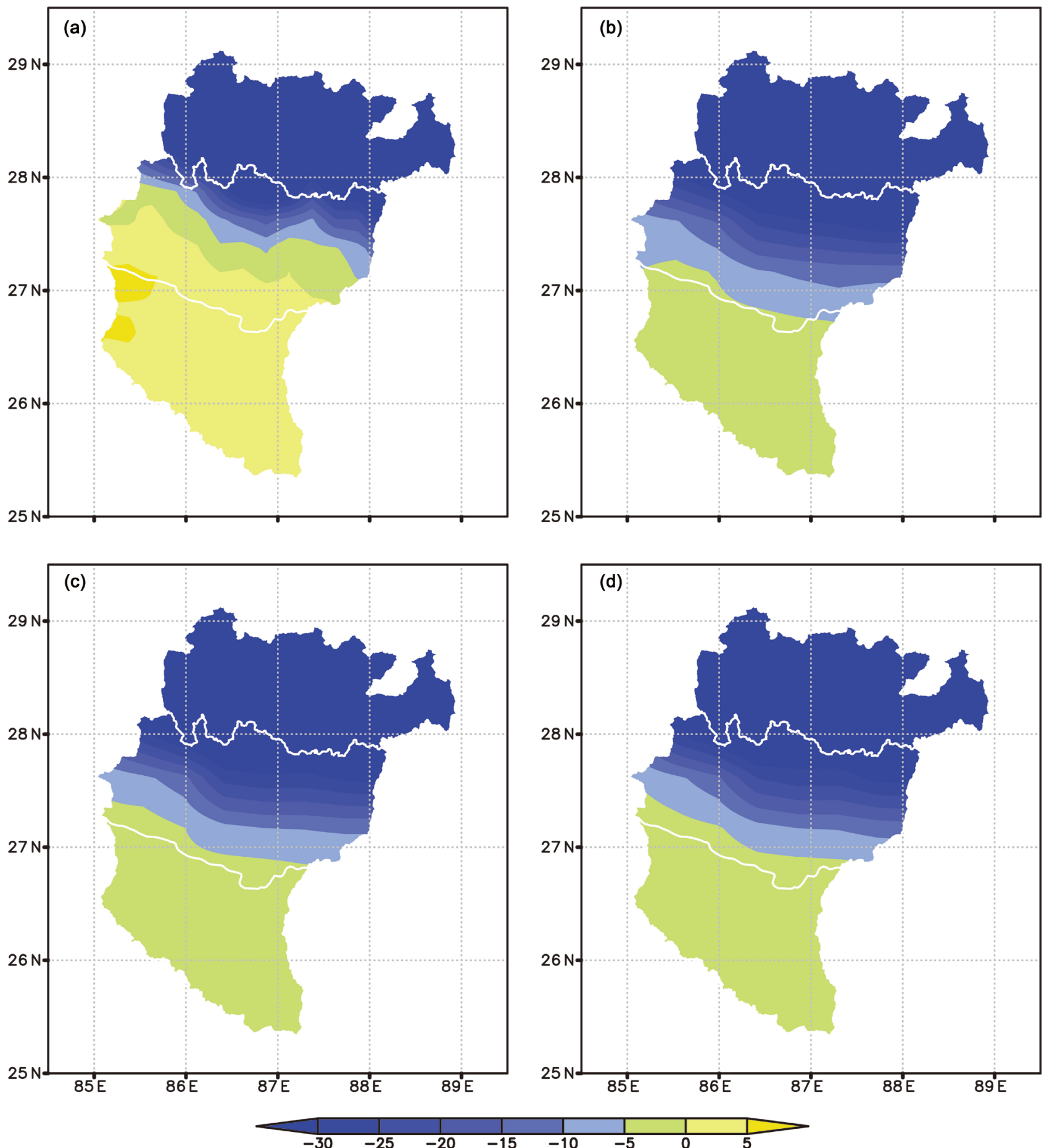

Figure 10. Lowest minimum temperature $\left({ }^{\circ} \mathrm{C}\right)$. (a) APHRODITE (b) Q0 simulation (c) Q1 simulation (d) Q14 simulation.

Spatial distribution of projected changes in summer and winter season rainfall for three simulations are provided in Figure 12 and Figure 13 respectively. During summer season, Q0 and Q1 simulation projected increase in rainfall, mostly up to $10 \%$ over the plains area and southern part of the middle mountains, and decrease over the northern part of the middle mountains and the trans-Himalayan area. Q14 simulation projected decrease in rainfall over almost 

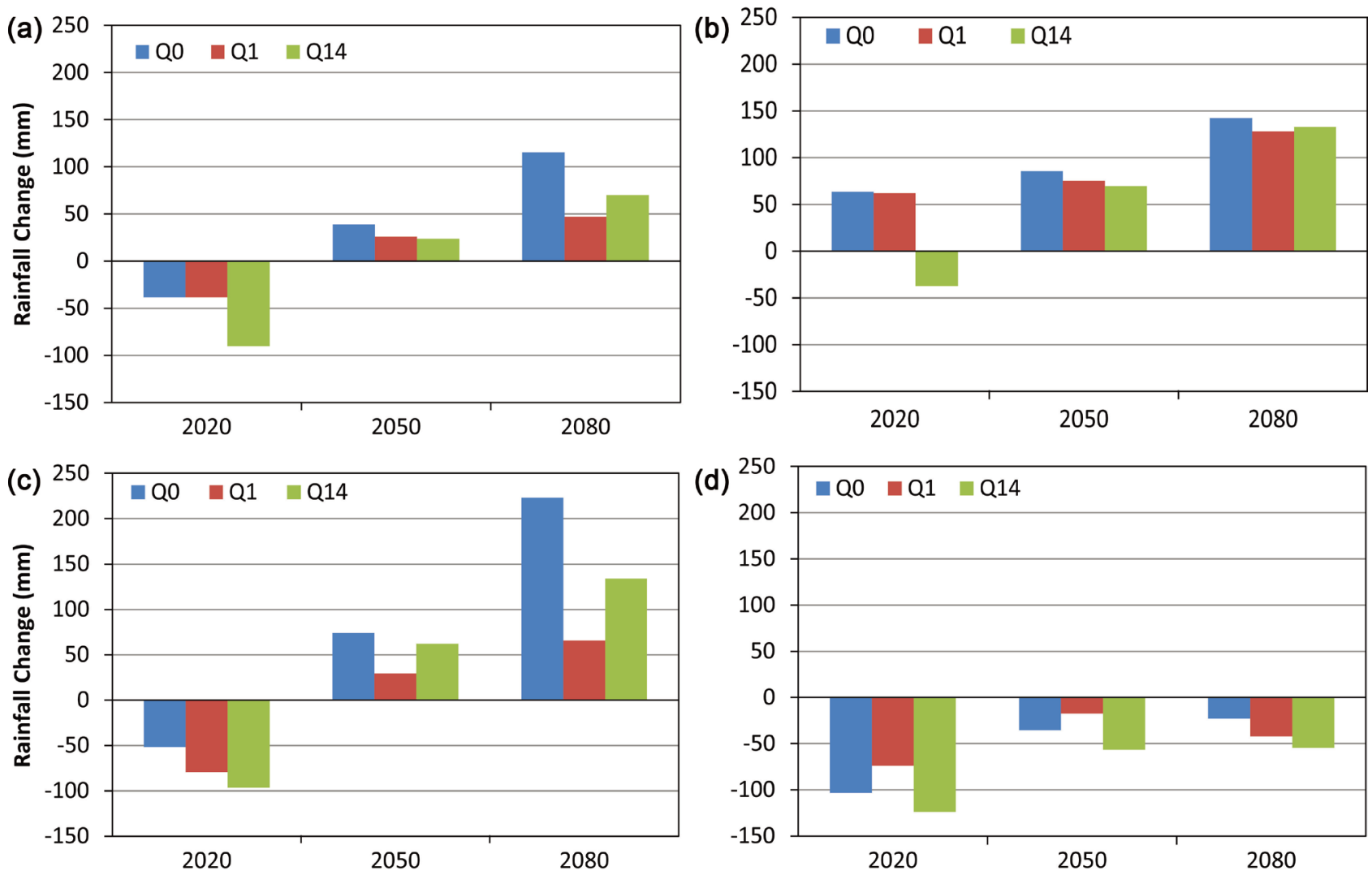

Figure 11. Projected changes in summer rainfall for three time slices in the future (a) whole basin (b) southern plain (c) middle mountain, and (d) trans-Himalaya.

all parts of the basin, mostly up to $10 \%$ in the south and more in the north. Spatially, there is general agreement between all three simulations on rainfall projection for the 50's time slice. During the 80 's, Q1 simulation projected a slightly larger area of decrease in rainfall over the northern part of the middle mountains and the trans-Himalaya. For the 20's, all three simulations show decrease in rainfall during winter in the entire basin, with more than $50 \%$ decrease over the southern part of the basin by Q1 scenario. However during the 50's, the result is mixed: Q0 projects increase in the entire basin and Q1 projects decrease, whereas Q14 projects increase over the middle mountains and trans-Himalaya and decrease in the south. Towards the end of the $21^{\text {st }}$ century, there is projected increase in rainfall over the north and decrease in the south.

\subsection{Rainfall Frequency and Intensity}

Projections of future changes in rainfall frequency or the number of rainy days and simple daily rainfall intensity (mm/day) are shown in Figure 14 and Figure 15 respectively. Except for a small area over the eastern part of the middle mountain area, all three simulations show decrease in rainfall frequency by up to five days. Over the southern plains, further decrease in the number of rainy days is projected for all three simulations. During the 80 's, there is decrease by $10-25$ days, 5 - 20 days and up to 15 days for Q0, Q1 and Q14 simulations respectively. 

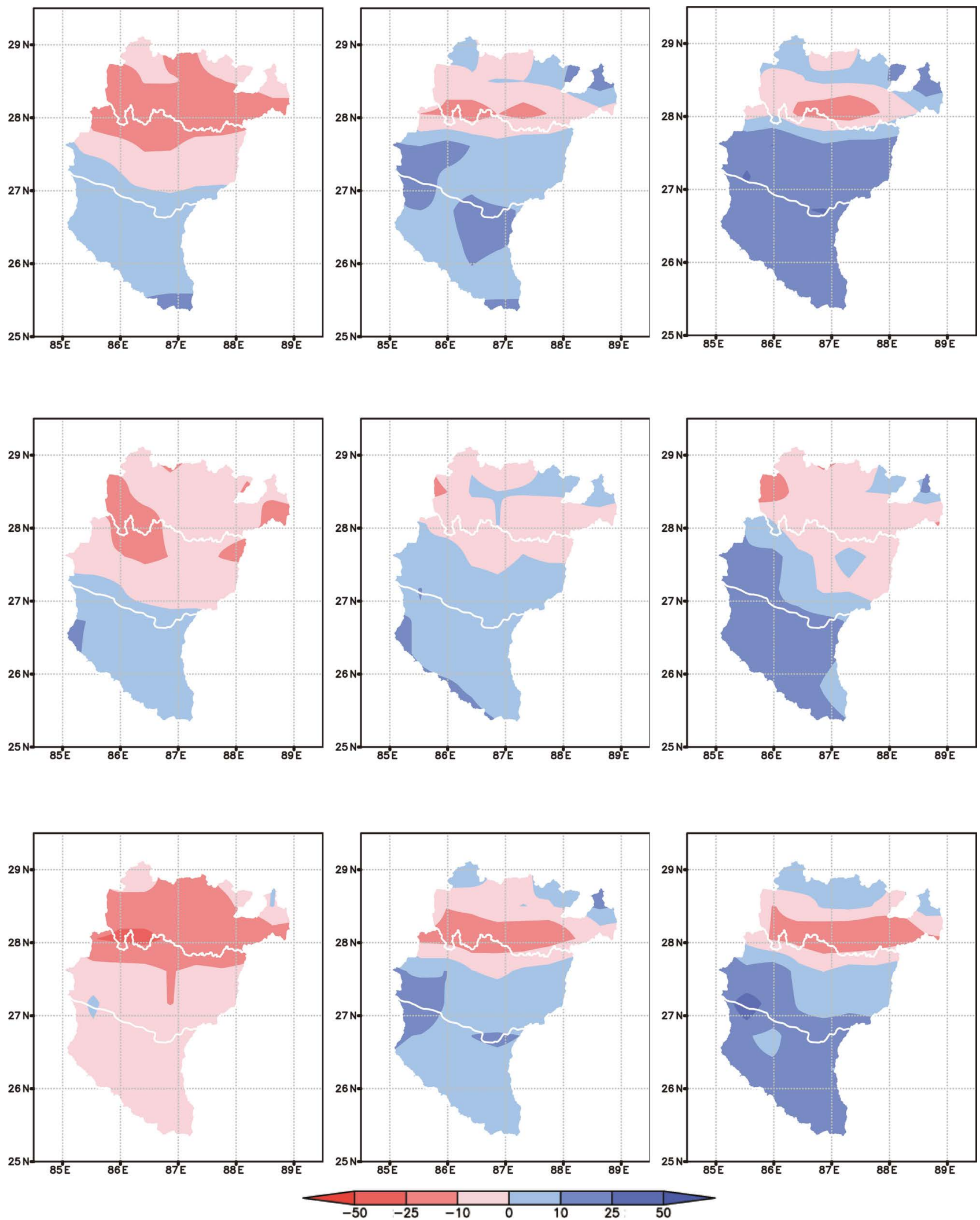

Figure 12. Projected change in mean summer monsoon rainfall (\%) with respect to baseline 1961-1990 in the 2020s (left column), 2050s (middle column), and 2080s (right column) for the three simulations Q0 (top row), Q1 (middle row), and Q14 (bottom row). 

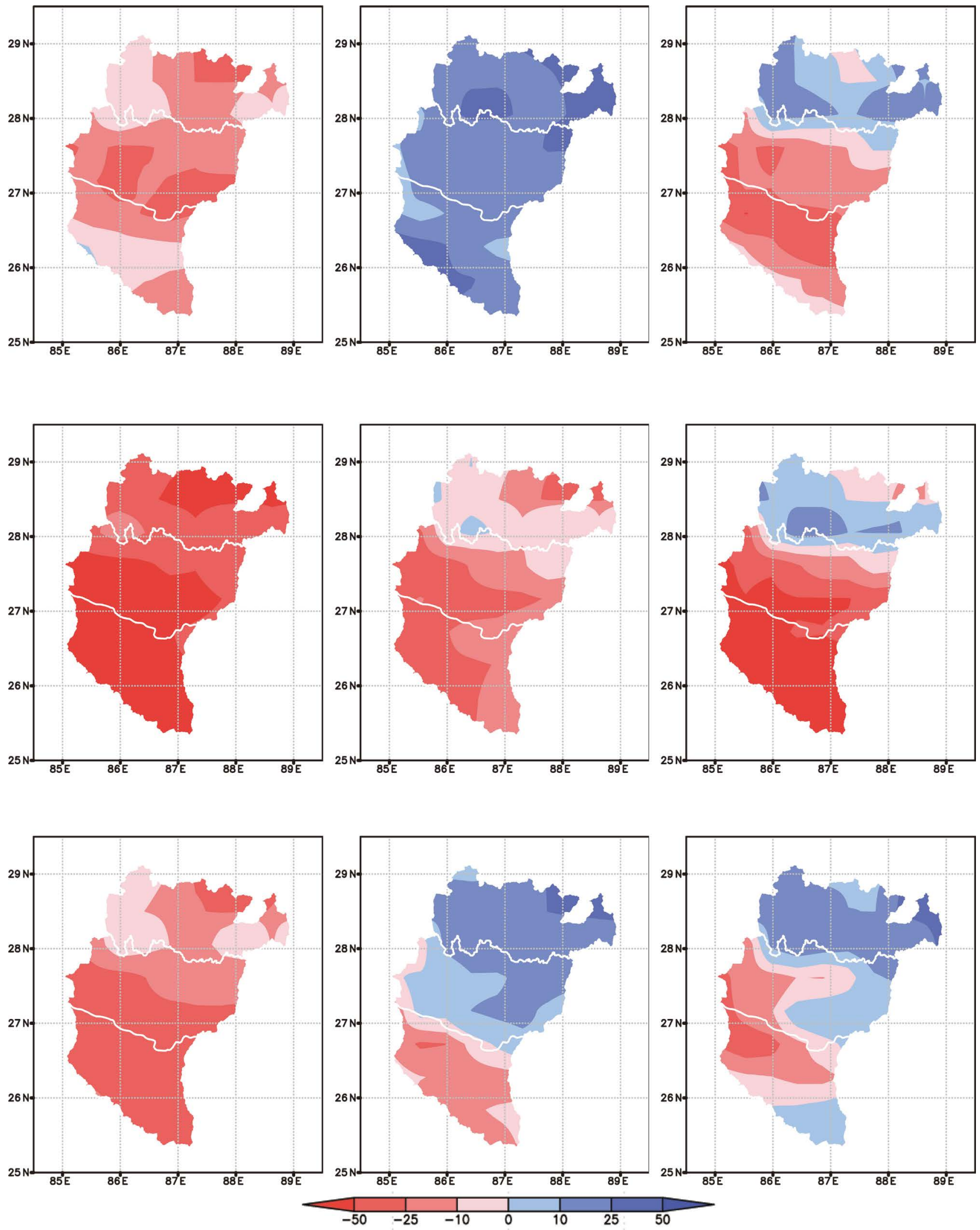

Figure 13. Projected change in mean winter season rainfall (\%) with respect to baseline 1961-1990 in the 2020s (left column), 2050s (middle column), and 2080s (right column) for the three simulations Q0 (top row), Q1 (middle row), and Q14 (bottom row). 

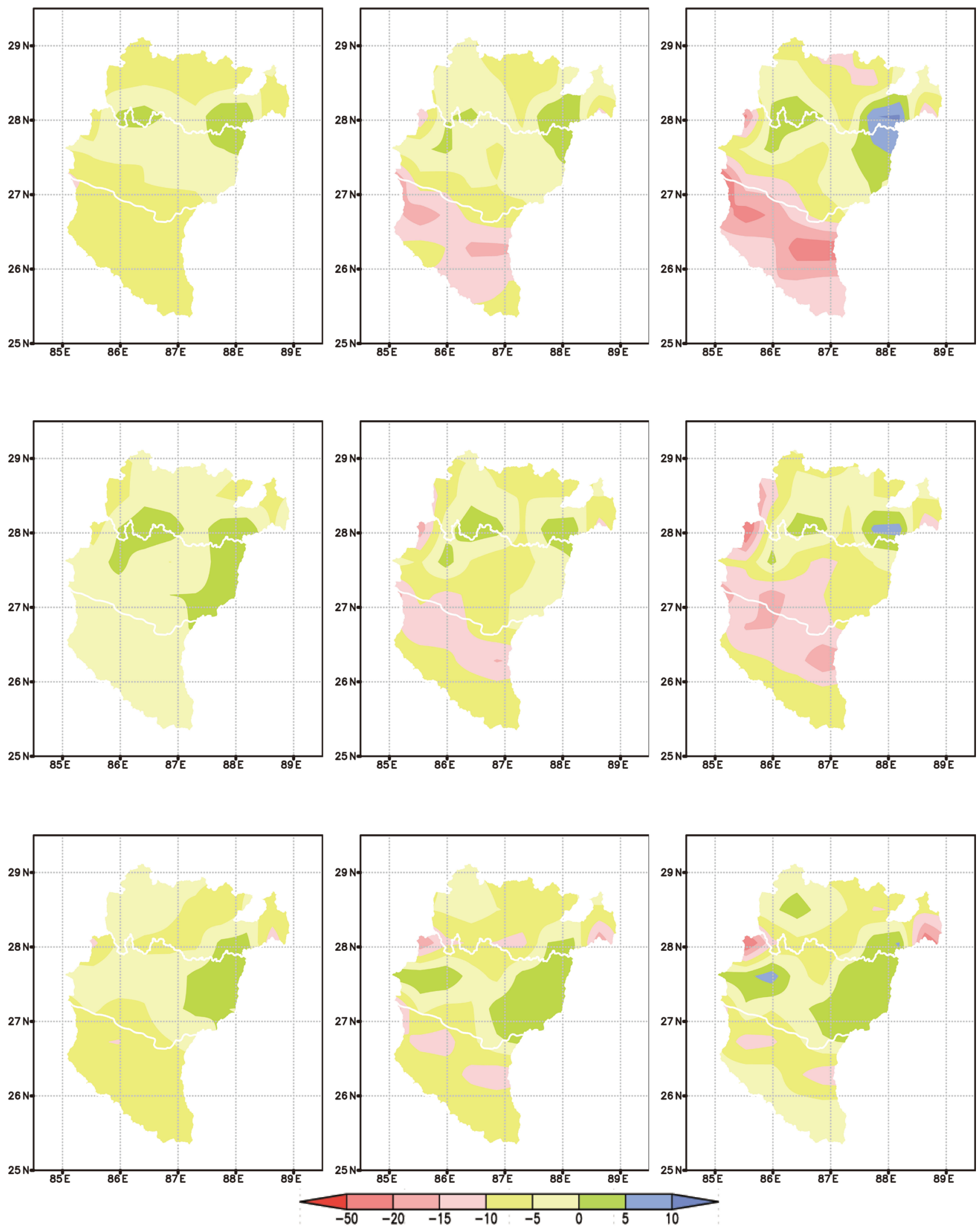

Figure 14. Projected change in the number of rainy days in a year with respect to baseline 1961-1990 in the 2020s (left column), 2050s (middle column), and 2080s (right column) for the three simulations Q0 (top row), Q1 (middle row), and Q14 (bottom row). 

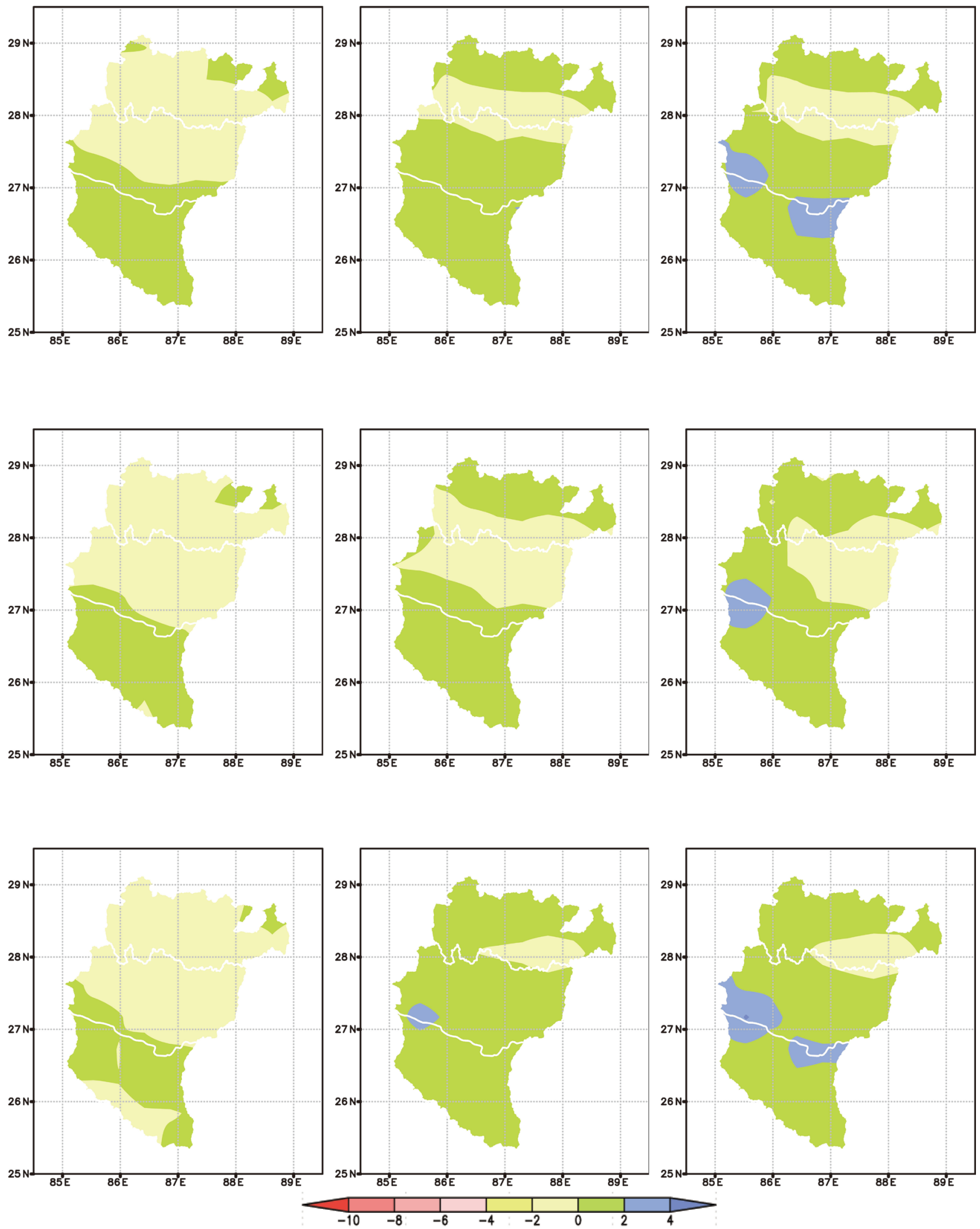

Figure 15. Projected change in simple daily rainfall intensity (mm/day) with respect to baseline 1961-1990 in the 2020s (left column), 2050s (middle column), and 2080s (right column) for the three simulations Q0 (top row), Q1 (middle row), and Q14 (bottom row). 
On the other hand, a slight increase (up to $2 \mathrm{~mm} /$ day) in rainfall intensity is projected over the southern plains, while a decrease over northern area (middle mountains and trans-Himalayan area) is projected for the near future, as shown in Figure 15. But towards the end of the century, with the exception of a small area over the middle mountains and trans-Himalayan border, rainfall intensity is projected to increase by about $2 \mathrm{~mm}$ /day compared to the baseline, indicating some increase in high intensity rainfall in the future.

\subsection{Projected Changes in Temperature}

Simulations of surface air temperature show progressive rise in both the maximum and minimum temperatures through the given time slices. Table 3 provides averages of the three simulations for summer maximum and winter minimum temperature anomalies against the baseline over the whole basin and its three physiographic zones for the three time slices. These temperature anomalies are the thirty years averages difference between baseline and the projection period. The change in temperature from the baseline (1961-1990) for the whole Koshi basin and its different physiographic zones are shown in Figure 16. Again progressive warming is projected for both summer and winter seasons. Average warming (Q0, Q1 \& Q14) from the base period for the three time slices over whole the Koshi basin are $1.2^{\circ} \mathrm{C}, 2.8^{\circ} \mathrm{C}$ and $3.7^{\circ} \mathrm{C}$ for maximum temperature and $2.0^{\circ} \mathrm{C}, 3.7^{\circ} \mathrm{C}$ and $5.3^{\circ} \mathrm{C}$ for minimum temperature during winter season. In all the simulations and over all the physiographic zones, more warming is projected for winter than for summer. Towards the end of the century, there is more warming over the trans-Himalaya during summer and over the southern plains during winter. Spatial distribution of annual mean temperature is given in Figure 17. Although there is no definitive pattern in warming, progressive warming from the near future $\left(1^{\circ} \mathrm{C}-2^{\circ} \mathrm{C}\right)$, middle of the century $\left(2^{\circ} \mathrm{C}-4^{\circ} \mathrm{C}\right)$ and in the end of the century $\left(3^{\circ} \mathrm{C}-6^{\circ} \mathrm{C}\right)$ is simulated. Rajbhandari [20] has reported similar projections over the Koshi basin using CMIP5 GCMs.

\subsection{Extreme Temperature}

Three simulation results indicate that daily extreme temperature may intensify in the future. The spatial pattern of the changes in the highest maximum temperature suggests warming of $1^{\circ} \mathrm{C}-2^{\circ} \mathrm{C}$ (Figure 18) in the 2011-2040 period,

Table 3. Projected seasonal maximum and minimum temperature anomalies $\left({ }^{\circ} \mathrm{C}\right)$ against the baseline over the Koshi basin and its physiographic zones for three time slices.

\begin{tabular}{ccccccc}
\hline & \multicolumn{3}{c}{ (a) Summer maximum } & \multicolumn{3}{c}{ (b) Winter minimum } \\
\hline & $\Delta 20 \mathrm{~s}$ & $\Delta 50 \mathrm{~s}$ & $\Delta 80 \mathrm{~s}$ & $\Delta 20 \mathrm{~s}$ & $\Delta 50 \mathrm{~s}$ & $\Delta 80 \mathrm{~s}$ \\
$\mathrm{WK}$ & 1.2 & 2.5 & 3.7 & 1.9 & 3.8 & 5.4 \\
$\mathrm{SP}$ & 1.3 & 2.6 & 3.8 & 1.7 & 4.1 & 5.5 \\
$\mathrm{MM}$ & 1.1 & 2.3 & 3.3 & 2.1 & 3.5 & 5.0 \\
$\mathrm{TH}$ & 1.4 & 2.6 & 4.0 & 1.9 & 3.2 & 4.7 \\
\hline
\end{tabular}



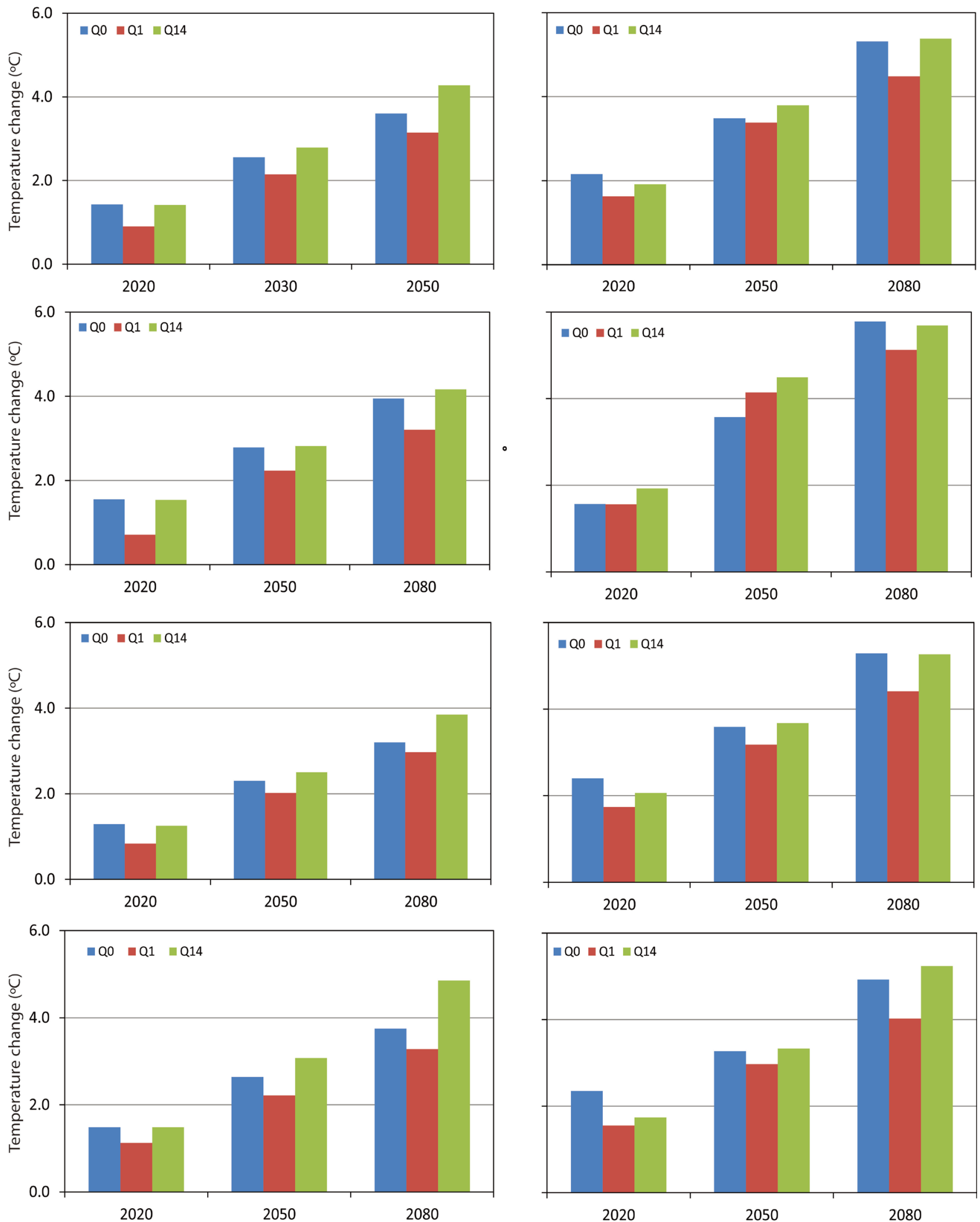

Figure 16. Changes in future projection of the temperature $\left({ }^{\circ} \mathrm{C}\right)$ from the baseline over the whole Koshi basin (top row), southern plains (second row), middle mountains (third row) and trans-Himalaya (fourth row). Left panel-summer season maximum temperature and right panel—winter season minimum temperature. 

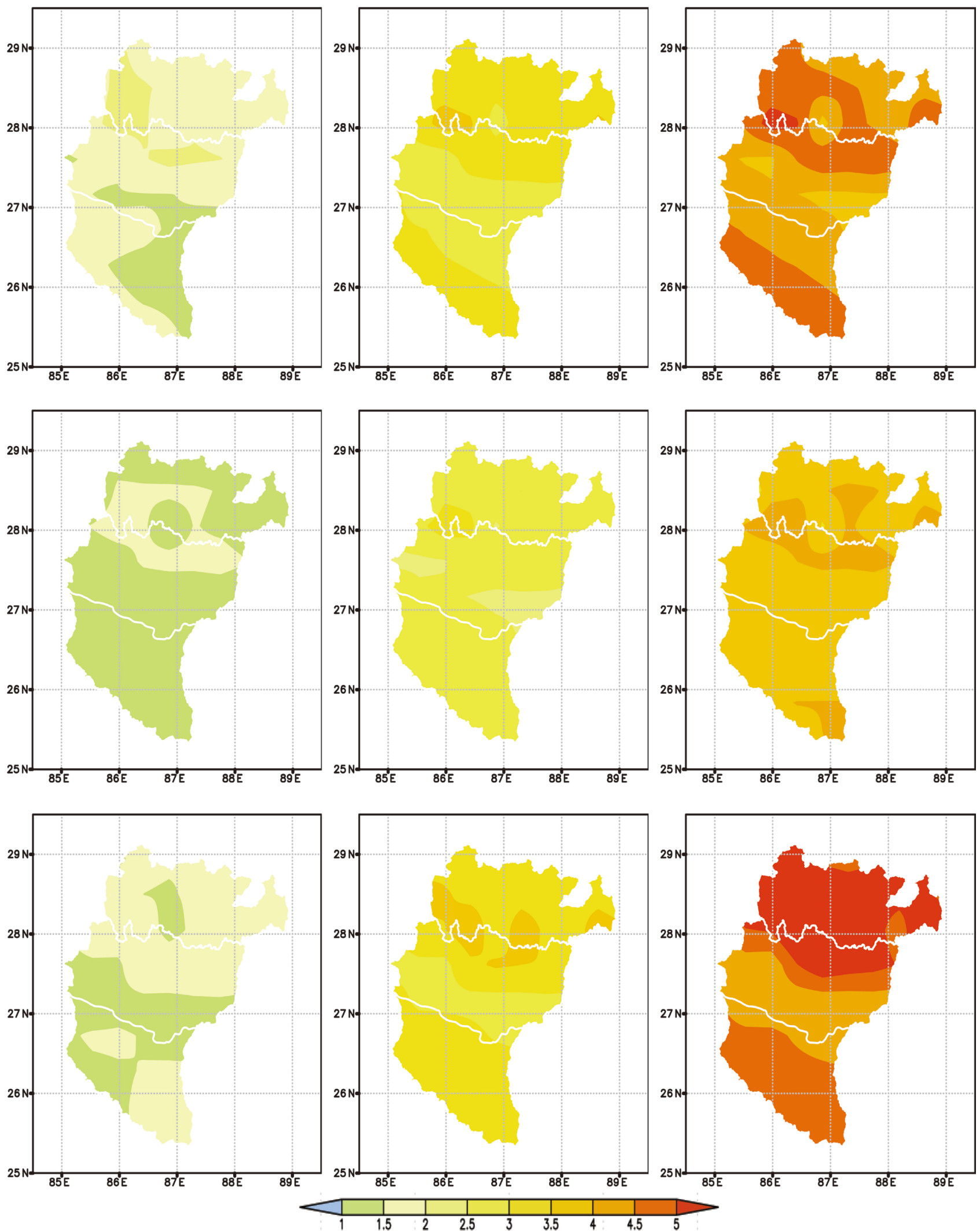

Figure 17. Projected change in annual mean surface temperature $\left({ }^{\circ} \mathrm{C}\right)$ with respect to baseline $1961-1990$ in the 2020 s (left column), 2050s (middle column), and 2080s (right column) for the three simulations Q0 (top row), Q1 (middle row), and Q14 (bottom row). 



Figure 18. Projected change in highest maximum temperature $\left({ }^{\circ} \mathrm{C}\right)$ with respect to baseline 1961-1990 in the 2020s (left column), 2050s (middle column), and 2080s (right column) for the three simulations Q0 (top row), Q1 (middle row), and Q14 (bottom row). 
which may exceed up to $6^{\circ} \mathrm{C}$ over the higher Himalayan parts of the middle mountains in the distant future.

\section{Conclusions}

Presented below is the assessment of expected future changes in rainfall and temperature over the Koshi basin under the IPCC's SRES A1B global warming scenario based on the PRECIS model.

- The PRECIS model showed ability to simulate climate scenario for both seasonal rainfall and temperature reasonably well but there were quantitative biases. There was an overestimation of rainfall for both summer and winter seasons and a cold bias for temperature.

- Rainfall is expected to decrease in the near future (2011-2040) and then progressively increase towards the end of the $21^{\text {st }}$ century.

- Over the southern plains, summer monsoon is expected to increase from the base period towards the end of the $21^{\text {st }}$ century.

- Over the trans-Himalayan area, summer monsoon rainfall is projected to decrease.

- The projected change in the number of rainy days differs among the ensemble; however, in future, the number of rainy days may decrease and there may be increase in rainfall intensity over the southern plains.

- Progressive increase in maximum and minimum temperatures is projected for the future. All three simulations indicated a significant rise in temperature (between $4^{\circ} \mathrm{C}-6^{\circ} \mathrm{C}$ ) throughout the basin.

- Analysis of extreme temperature indicates that daily maximum temperature may be more intense in the future.

The above assessment is indicative of the range of expected changes in rainfall and temperature from the PRECIS baseline. It is important to note that projections contain significant uncertainties. The study was limited as it was based on a few simulations from a single high-resolution regional climate model.

\section{Acknowledgements}

This study was conducted under the Koshi Basin Programme at ICIMOD, funded by the Department of Foreign Affairs and Trade (DFAT) of Australia. This study was partially supported by the core funds of ICIMOD (contributed by the governments of Afghanistan, Australia, Austria, Bangladesh, Bhutan, China, India, Myanmar, Nepal, Norway, Pakistan, Switzerland and the United Kingdom). The views and interpretations in this publication are those of the authors and not necessarily attributable to ICIMOD.

\section{References}

[1] DHM (2015) Study of Climate and Climatic Variation over Nepal. Department of Hydrology and Meteorology, Kathmandu, 43.

[2] Bookhagen, B. and Burbank, D.W. (2010) Toward a Complete Himalayan Hydro- 
logical Budget: Spatiotemporal Distribution of Snowmelt and Rainfall and Their Impact on River Discharge. Journal of Geophysical Research: Earth Surface, 115, F03019. https://doi.org/10.1029/2009JF001426

[3] Eriksson, M., Xu, J., Shrestha, A.B., Vaidya, R.A., Nepal, S. and Sandström, K. (2009) The Changing Himalayas: Impact of Climate Change on Water Resources and Livelihoods in the Greater Himalayas. ICIMOD, Kathmandu.

[4] WMO (2015). https://www.wmo.int/worldmetday2015/content/knowledge

[5] Lutz, A.F., Immerzeel, W.W., Shrestha, A.B. and Bierkens, M.F.P. (2014) Consistent Increase in High Asia's Runoff Due to Increasing Glacier Melt and Precipitation. Nature Climate Change, 4, 587-592. https://doi.org/10.1038/nclimate2237

[6] Dhimal, M., Ahrens, B. and Kuch, U. (2015) Climate Change and Spatiotemporal Distributions of Vector-Borne Diseases in Nepal-A Systematic Synthesis of Literature. PLOS ONE, 10, e0129869. https://doi.org/10.1371/journal.pone.0129869

[7] Conway, D. (1996) The Impacts of Climate Variability and Future Climate Change in the Nile Basin on Water Resources in Egypt. International Journal of Water Resources Development, 12, 277-296. https://doi.org/10.1080/07900629650178

[8] IPCC (2007) Climate Change 2007: The Physical Science Basis Contribution of Working Group I to the Fourth Assessment Report of the IPCC.

[9] Barnet, T.P., Adam, J.C. and Lettenmaier, D.P. (2005) Potential Impacts of a Warming Climate on Water Availability in Snow-Dominated Regions, Nature, 438, 303-309.

[10] Immerzeel, W., Beek, L.V. and Bierkens, M. (2010) Climate Change Will Affect the Asian Water Towers. Science, 328, 1382-1385. https://doi.org/10.1126/science.1183188

[11] Panday, P.K., Frey, K.E. and Ghimire, B. (2011) Detection of the Timing and Duration of Snowmelt in the Hindu Kush-Himalaya Using QuikSCAT, 2000-2008. Environmental Research Letters, 6, 1-13.

[12] Immerzeel, W.W., Droogers, P., Jong, S.M.D. and Bierkens, M.F.P. (2009) Large-Scale Monitoring of Snow Cover and Runoff Simulation in Himalayan River Basins using Remote Sensing. Remote Sensing of Environment, 113, 40-49. https://doi.org/10.1016/j.rse.2008.08.010

[13] Panday, P.K., Thibeault, J. and Frey, K.E. (2014) Changing Temperature and Precipitation Extremes in the Hindu Kush-Himalayan Region: An Analysis of CMIP3 and CMIP5 Simulations and Projections. International Journal of Climatology, 35, 3058-3077.

[14] Rupa Kumar, K., Sahai, A.K., Kumar, K.K., Patwardhan, S.K., Mishra, P.K., Revadkar, J.V., Kamala, K. and Pant, G.B. (2006) High-Resolution Climate Change Scenario for India for the 21st Century. Current Science, 90, 334-345.

[15] Kumar, K.K., Patwardhan, S.K., Kulkarni, A., Kamala, K., Rao, K.K. and Jones, R. (2011) Simulated Projections for Summer Monsoon Climate over India by a High-Resolution Regional Climate Model (PRECIS). Current Science, 101, 312-326.

[16] Syed, F.S., Iqbal, W., Syed, A.B. and Rasul, G. (2013) Uncertainties in the Regional Climate Models Simulations of South Asian Summer Monsoon and Climate Change. Climate Dynamics, 42, 2079-2097.

[17] Kulkarni, A., Patwardhan, S., Kumar, K.K., Ashok, K. and Krishnan, R. (2013) Projected Climate Change in the Hindu Kush Himalayan Region by using the High-Resolution Regional Climate Model PRECIS. Mountain Research and Development, 33, 142-151. https://doi.org/10.1659/MRD-JOURNAL-D-11-00131.1 
[18] Rajbhandari, R., Shrestha, A.B., Kulkarni, A., Patwardhan, S.K. and Bajracharya, S.R. (2015) Projected Changes in Climate over the Indus River Basin using a High Resolution Regional Climate Model (PRECIS). Climate Dynamics, 44, 339-357. https://doi.org/10.1007/s00382-014-2183-8

[19] IPCC (2001) Special Report: Emissions Scenarios. Summary for Policymakers. https://ipcc.ch/pdf/special-reports/spm/sres-en.pdf

[20] Rajbhandari, R., Shrestha, A.B., Nepal, S. and Wahid, S. (2016) Projection of Future Climate over the Koshi River Basin Based on CMIP5 GCMs. Atmospheric and Climate Sciences, 6, 190-204. https://doi.org/10.4236/acs.2016.62017

[21] Shrestha, A.B., Eriksson, M., Mool, P., Ghimire, P., Mishra, B. and Khanal, N.R. (2010) Glacial Lake Outburst Flood Risk Assessment of Sun Koshi Basin, Nepal. Geomatics, Natural Hazards and Risk, 1, 157-169. https://doi.org/10.1080/19475701003668968

[22] Neupane, N., Murthy, M.S.R., Rasul, G., Wahid, S., Shrestha, A.B. and Uddin, K. (2013) Integrated Biophysical and Socioeconomic Model for Adaptation to Climate Change for Agriculture and Water in the Koshi Basin. In: Handbook of Climate Change Adaptation, Springer, Berlin, Heidelberg, 978.

[23] Agarwal, A., Babel, M.S., Maskey, S., Shrestha, S., Kawasaki, A. and Tripathi, N.K. (2016) Analysis of Temperature Projections in the Koshi River Basin, Nepal. International Journal of Climatology, 36, 266-279. https://doi.org/10.1002/joc.4342

[24] Nepal, S. (2016) Impacts of Climate Change on the Hydrological Regime of the Koshi River Basin in the Himalayan Region. Journal of Hydro-Environment Research, 10, 76-89. https://doi.org/10.1016/j.jher.2015.12.001

[25] Goswami, B.N., Venugopal, V., Sengupta, D., Madhusoodanan, M.S. and Xavier, P.K. (2006) Increasing Trend of Extreme Rain Events over India in a Warming Environment. Science, 314, 1442-1445. https://doi.org/10.1126/science.1132027

[26] Nepal, S., Flügel, W.A. and Shrestha, A.B. (2014) Upstream-Downstream Linkages of Hydrological Processes in the Himalayan Region. Ecological Processes, 3, 1-16. https://doi.org/10.1186/s13717-014-0019-4

[27] Chalise, S.R. (1994) Mountain Environments and Climate Change in the Hindu Kush Himalayas. In: Beniston, M., Ed., Mountain Environments in Changing Climates, Routledge, London, 383-404.

https://doi.org/10.4324/9780203424957_chapter_24

[28] Shrestha, A.B., Cameron, P.W., Jack, E.D. and Paul, A.M. (2000) Precipitation Fluctuations in the Nepal Himalaya and Its Vicinity and Relationship with Some Large Scale Climatological Parameters. International Journal of Climatology, 20, 317-327.

https://doi.org/10.1002/(SICI)1097-0088(20000315)20:3<317::AID-JOC476>3.0.CO; $\underline{2-G}$

[29] Shrestha, M.L. (2000) Inter-Annual Variation of Summer Monsoon Rainfall over Nepal and Its Relation to Southern Oscillation Index. Meteorology and Atmospheric Physics, 75, 21-28. https://doi.org/10.1007/s007030070012

[30] Ichiyanagi, K., Yamanaka, M.D., Yoshitaka, M.Y. and Vaidya, B.K. (2007) Precipitation in Nepal between 1987 and 1996. International Journal of Climatology, 27, 1753-1762. https://doi.org/10.1002/joc.1492

[31] Nayava, J.L. (1974) Climate of Nepal. The Himalayan Review, 11, 15-20.

[32] Inoue, J. (1976) Climate of Khumbu Himal. Seppyo, 38, 66-73. https://doi.org/10.5331/seppyo.38.Special_66 
[33] Karki, R., Talchabhdel, R., Aalto, J. and Baidya, S.K. (2015) New Climatic Classification of Nepal. Theoretical and Applied Climatology, 125, 799-808.

[34] Kripalani, R.H., Oh, J.H., Kulkarni, A., Sabade, S.S. and Chaudhari, H.S. (2007) South Asian Summer Monsoon Precipitation Variability: Coupled Climate Model Simulations and Projections under IPCC AR4. Theoretical and Applied Climatology, 90, 133-159. https://doi.org/10.1007/s00704-006-0282-0

[35] Patwardhan, S.K. (2013) The Study of Impact of Climate Change on the Characteristics of Indian Summer Monsoon using Regional Climate Model. Dissertation, University of Pune, Pune.

[36] Yatagai, A., Arakawa, O., Kamiguchi, K., Kawamoto, H., Nodzu, M.I. and Hamada, A. (2009) A 44-Year Daily Gridded Precipitation Dataset for Asia Based on a Dense Network of Rain Gauges. Scientific Online Letters on the Atmosphere, 5, 137-140.

[37] Agarwal, A., Babel, M.S. and Maskey, S. (2014) Analysis of Future Precipitation in the Koshi River Basin, Nepal. Journal of Hydrology, 513, 422-434. https://doi.org/10.1016/j.jhydrol.2014.03.047

[38] Andermann, C., Bonnet, S. and Gloaguen, R. (2011) Evaluation of Precipitation Data Sets along the Himalayan Front. Geochemistry, Geophysics, Geosystems, 12 , 1-16. https://doi.org/10.1029/2011GC003513

[39] Duncan, J.M.A. and Biggs, E.M. (2012) Assessing the Accuracy and Applied Use of Satellite-Derived Precipitation Estimates over Nepal. Applied Geography, 34, 626-638. https://doi.org/10.1016/j.apgeog.2012.04.001

[40] Yatagai, A., Kamiguchi, K., Arakawa, O., Hamada, A., Yasutomi, N. and Kitoh, A. (2012) APHRODITE: Constructing a Long-Term Daily Gridded Precipitation Dataset for Asia Based on a Dense Network of Rain Gauges. Bulletin of the American Meteorological Society, 93, 1401-1415. https://doi.org/10.1175/BAMS-D-11-00122.1

[41] Yasutomi, N., Hamada, A. and Yatagai, A. (2011) Development of a Long-Term Daily Gridded Temperature Dataset and Its Application to Rain/Snow Discrimination of Daily Precipitation. Global Environmental Research, 15, 165-172.

[42] Sheffield, J., Goteti, G. and Wood, E.F. (2006) Development of a 50-Year High-Resolution Global Dataset of Meteorological Forcings for Land Surface Modeling. Journal of Climate, 19, 3088-3111. https://doi.org/10.1175/JCLI3790.1 